\title{
CRKVINE U VESELO KOD BUGOJNA U ZAPADNOM DIJELU SREDNJE BOSNE
}

\author{
Ante ŠKEGRO \\ Hrvatski institut za povijest \\ HR-10000 Zagreb \\ Ppatička 10 \\ E-pošta: askegro@isp.hr \\ Ajla SEJFULI \\ Zavičajni muzej Travnik \\ $\mathrm{BiH}-72270$ Travnik \\ Mehmed-paše Kukavice 1 \\ E-pošta: asejfuli@gmail.com \\ Marko ĆORIĆ \\ Franjevačka klasična gimnazija Visoko \\ $\mathrm{BiH}$-71300 Visoko \\ Bosne Srebrene 4 \\ E-pošta: marko.coric@yahoo.com
}

\author{
UDK: 903/904(497.6)"13/14" \\ Prethodno priopćenje \\ Primlieno: 14. studenoga 2016 \\ Prihvaćeno: 5. travnja 2017
}

\section{Sažetak}

Stručna je literatura uglavnom bila suglasna da su franjevci u Veseloj kod Bugojna u zapadnom dijelu srednje Bosne imali svoju crkvu i samostan, koji su razoreni tijekom osmanlijskih nasrtaja na sâmo središte Bosanskoga Kraljevstva u prvoj polovici 15. st. Spominju ih jedna krivotvorena povelja iz 16. st., trojica franjevačkih kroničara iz 17. i 18. st. te jedan franjevački putopisac iz 19. st. Locira ih se na Crkvine kod srednjovjekovne utvrde Vesela Straža. Arheološka iskopavanja izvođena na Crkvinama od 10. do 20. prosinca 2014., od 8. do 14. lipnja 2015. te od 9. do 25. rujna 2015. nisu iznjedrila ništa što bi to nedvojbeno i potvrdio. Nedostatak crijepa i cigle te tragovi gareža svjedoče da je objekt na Crkvinama bio pokriven šindrom te da je stradao u požaru. Njegove dimenzije, struktura zidova, 
dovratnici i nadvratnici i njihova ornamentacija te ostatci freski svjedoče da se radi o građevini koja je pripadala najvišim strukturama bosansko-humske političke elite.

Ključne riječi: Crkvine; Vesela Straža; Bugojno; kasni srednji vijek.

\section{Uvod}

Crkvine su se ugnijezdile u uskoj izduženoj prodolini, stiješnjenoj planinskim masivima Garačkih i Veseoških podova. Kroz nju protiče potok Pršljanica i vijuga put kojim su karavane iz istočne i srednje Bosne, preko Lašve, Uskoplja, Kupreške visoravni, Livna i Klisa milile k dalmatinskim komunama, ${ }^{1}$ s tovarima olova, srebra, željeza, smole, voska, meda, kožâ, krzna, mesa, sira, vune, tkanina, oružja, oruđa, s pticama za lov, stokom, najamnom i robovskom radnom snagom. ${ }^{2} \mathrm{U}$ obrnutom smjeru prispijevali su sol, maslinovo ulje, vino, riba, skupocjene tkanine i drugi manufakturni proizvodi. ${ }^{3} \mathrm{Od}$ srednjovjekovne utvrde Vesela Straža (castra Veszela Straxa), pozicionirane na stjenovitome uzvišenju Kik odnosno Gradac, udaljene su oko $1,5 \mathrm{~km}$ zračne linije prema sjeverozapadu, od najbližeg suvremenog naselja Vesele oko 2,5 km, a od općinskog središta Bugojno 7 do $8 \mathrm{~km}$. Crkvine se, kao i spomenuta komunikacija, ali i ona dolinom susjednoga potoka Bunte kojom su karavane također prometovale $\mathrm{s}$ dalmatinskim komunama, odlično nadziru s Vesele Straže. Do razaranja 12. srpnja 2005. ${ }^{4}$ zidovi su joj mjestimice bili viši i od tri metra.

1 Ivan Pederin, "Split u XV. stoljeću (I)", u: Bosna franciscana: časopis Franjevačke teologije Sarajevo, br. XX/37, Sarajevo, 2012., str. 176.

2 Marko Šunjić, "Postupni uspon bosansko-venecijanskih ekonomskih odnosa u XV. stoljeću", u: Radovi Hrvatskog društva za znanost $i$ umjetnost, br. I., Sarajevo, 1993., str. 29-30; Isti, "Mjere, novac, zarade i cijene na dalmatinskobosanskom području (XIV. i XV. st.) II. dio", u: Radovi Hrvatskog društva za znanost i umjetnost, br. V., Sarajevo, 1997., str. 37-49.

3 Marko Šunjić, "Prilozi za istoriju bosansko-venecijanskih odnosa 14201463", u: Historijski zbornik, br. XIV., Zagreb, 1961., str. 131; Isti, "Postupni uspon", str. 20, 34-41; Isti, "Mjere, novac, zarade i cijene na dalmatinsko-bosanskom području (XIV. i XV. st.)", u: Radovi Hrvatskog društva za znanost $i$ umjetnost, br. IV., Sarajevo, 1996., str. 69.

4 "Lokalni tajkuni narušavaju istoriju. Razoren srednjovjekovni grad", u: Oslobođenje: bosanskohercegovačke nezavisne novine, Sarajevo, 6. 7. 2005.; BLANKA 


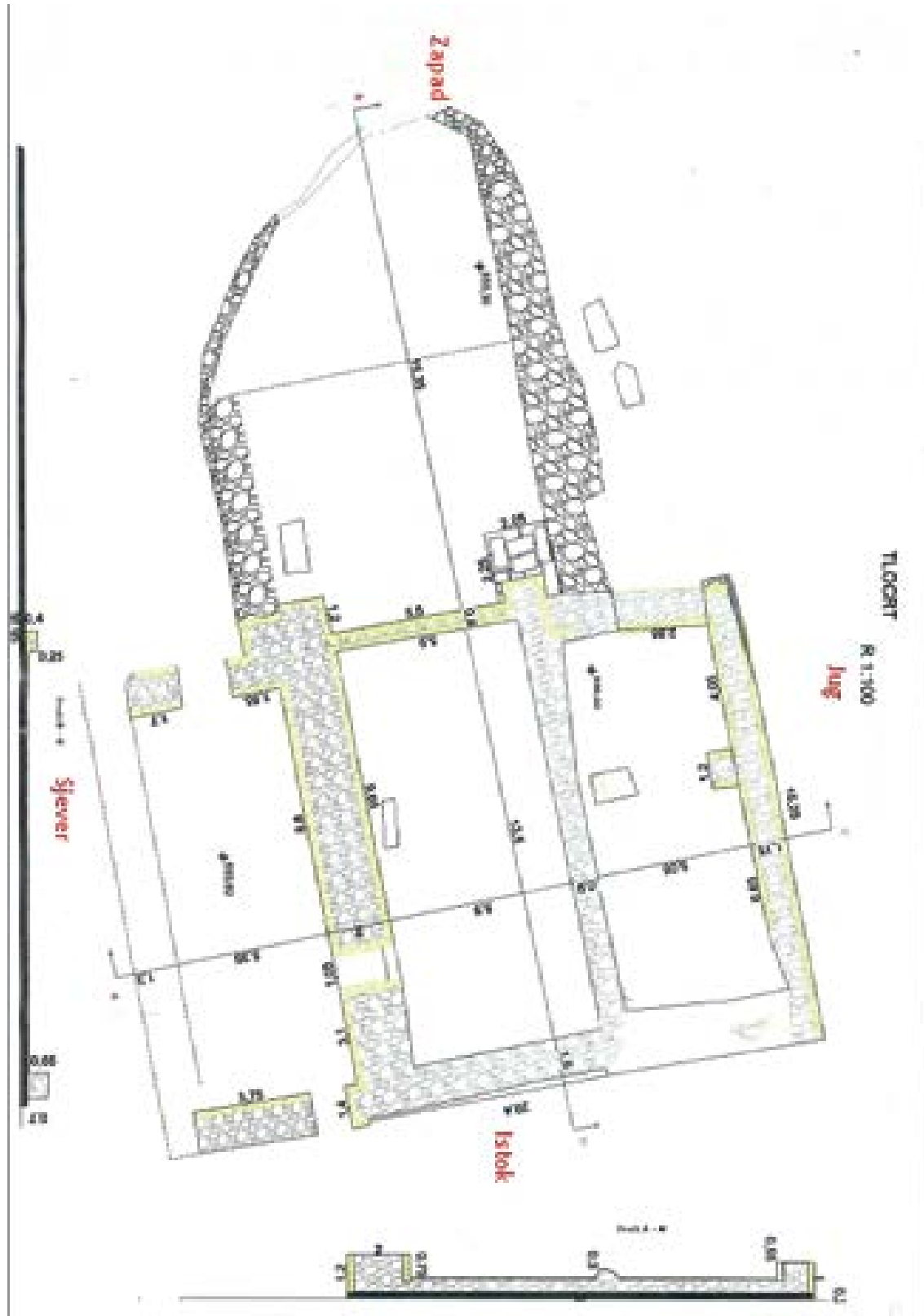

Plan 1. Plan kasnosrednjovjekovnog objekta na Crkvinama u Veseloj kod Bugojna Map 1. Map of the late medieval object on the Crkvine locality in Vesela near Bugojno 
A. ŠKEGRO - A. SEJFULI - M. ĆORIĆ - CRKVINE U VESELOJ KOD BUGOJNA...

\section{Poslovanje poduzetnika iz Vesele Straže s dalmatinskim komunama}

Arhivi dalmatinskih komuna svjedoče o intenzivnom poslovanju poduzetnika iz Vesele Straže ${ }^{5}$ tijekom prve polovice 15. st. s onima iz dalmatinskih komuna, ponajprije Splita, Trogira i Zadra. Među njima su bili i: Radivoj Biladino[vić], ${ }^{6}$ Radović Bralanović, ${ }^{7}$ Andrija Dobrošinović, ${ }^{8}$ Vućić Gavlović, ${ }^{9}$ Stipan Mazarić, ${ }^{10}$ Radelko Radasinović, ${ }^{11}$ Vućimil Radoević, ${ }^{12}$ Antol Nedopralić, ${ }^{13}$ braća Vlaćić i Grgur Vukanić, ${ }^{14}$ Vućić Zavlović ${ }^{15}$ i dr. ${ }^{16}$ Sa splitskim su trgovcima 1445. i 1446. godine poslovali i Grgur Vuković te Vlatko Vukavić. ${ }^{17}$ Dvojica trgovaca iz Vesele Straže, s još četvoricom iz Jajca, od splitskoga poduzetnika Venture Engleskog preuzeli su 1447. godine robu u vrijednosti oko 670 zlatnih dukata. ${ }^{18}$ Početkom svibnja 1455. četvorica poduzetnika iz Vesele Straže od splitskoga su trgovca Nikole Pecinića preuzeli oko 1760 litara maslinova ulja. ${ }^{19}$ Tvrtko Brajković iz Uskoplja, područja kojem je Vesela Straža bila upravno-gospodar-

MAGAš, "Bugojno: sretan epilog incidenta s razaranjem Vesele Straže. Utvrda iz srednjeg vijeka se obnavlja", u: Slobodna Dalmacija, Split, 20. 7. 2005.; SтоJAN MiLoš, "Baština. Husein Smajić uništio ostatke srednjovjekovnog grada Vesela Straža. Padobranci razorili bugojansku tvrđavu", Večernji list, Zagreb, 12. 7. 2005.

5 Vessela Straxa, Vexila Straxa.

6 Radivoy Biladino[vich].

7 Radovich Bralanovich.

8 Andreas Dobrossinovich.

9 Vuchich Gaulouich.

10 Stipanis Mazarich.

11 Radelchus Radassinouich.

12 Vuchimilus Radoevich.

13 Antol Nedopralich.

14 Vlachis et Gregorius Vucanich fratres.

15 Vuchich Zaulovich.

16 Salin Jalimam, "Srednjovjekovni grad Vesela Straža, prilozi za studiju", u: Glasnik Zemaljskog muzeja Sarajevo, br. 48/49, Sarajevo, 1996.-2001., str. 376.

17 M. ŠunjIć, "Postupni uspon", str. 33; Isti, Bosna i Venecija (odnosi u XIV. i XV. st.), HKD Napredak, Sarajevo, 1996., str. 332.

18 M. Šunjić, "Postupni uspon", str. 34; Isti, Bosna i Venecija, str. 334.

19 M. Šunjić, "Prilozi za istoriju", str. 131; Isti, "Mjere, novac, zarade i cijene", str. 69; Isti, Bosna i Venecija, str. 334. 
skim središtem, od splitskih je poduzetnika 1435. i 1436. godine preuzeo velike količine soli u zamjenu za srebro i vosak. ${ }^{20}$ Navedeni i drugi primjeri zorno svjedoče kako o okretnosti, tako i o ugledu poduzetnika iz Vesele Straže, odnosno Uskoplja, kojeg su imali u dalmatinskim komunama kao i bogatstvu s kojim su raspolagali. Stoga nije neopravdana konstatacija da je "glavno privredno uporište župe Uskoplje" Vesela Straža bilo "naprednije i razvijenije nego što to nama po izvorima izgleda". ${ }^{21}$ Do osmanlijske okupacije kroz Veselu Stražu (villa vessela straxa) milile su karavane s različitim robama iz Bosne prema istočnojadranskoj obali i obrnuto. Gdje se, pak, to naselje nalazilo još uvijek nije utvrđeno. Iz njega je do dalmatinskih komuna, ali i venecijanskih laguna prispijevala i najamna snaga, a u obrnutom smjeru naprednije ideje i vještine. Pojedinci iz Vesele Straže stjecali su graditeljsko-obrtničke vještine i u najboljim majstorskim radionicama dalmatinskih komuna. Takav je bio i Juraj Gradomilović, ${ }^{22}$ koji je svoje šestogodišnje naukovanje otpočeo 3. travnja 1455. u splitskoj radionici gotičko-renesansnoga graditelja Andrije Alešija (Andrea de Alesio). ${ }^{23}$ Za njega se nagađa da je sudjelovao i u gradnji kraljevskog Jajca. ${ }^{24}$ I ženska najamna snaga stjecala je različite vještine kod najuglednijih građana dalmatinskih i talijanskih komuna. Tako je, primjerice, 1454. godine Vladica Radojkovica iz Vesele Straže svoju djecu Radivoja i Milicu otpremila na osmogodišnje služenje k Giovanniju Contariniju u Chioggiu kod Venecije za 8, odnosno 6 dukata. ${ }^{25}$ Iste je godine Jelena iz Uskoplja otpočela svoje služenje kod Samaritane, udovice splitskoga liječnika Kristofora de Rubeisa de Salodije. ${ }^{26}$ Milojka iz Uskoplja otpočela je 1458. godine svoje desetogodišnje služenje za 10 dukata u Portogruaru kod Venecije. ${ }^{27}$

20 M. ŠunjIĆ, "Postupni uspon", str. 20.

21 Десанка Ковачевић-Којић, Градска насеља средњовјековне босанске државе, "Веселин Маслеша", Сарајево, 1978., str. 126.

22 Georgius Gradomilovich.

23 M. Šunjıć, "Postupni uspon", str. 12; Isti, Bosna i Venecija, str. 306.

24 Đuro Basler, "Gradomilić Juraj", u: Enciklopedija likovnih umjetnosti, DIni, sv. 2, "Leksikografski zavod", Zagreb, 1962., str. 445; Đоко MazALIĆ, Leksikon umjetnika slikara, vajara, graditelja, zlatara, kaligrafa i drugih koji su radili u Bosni i Hercegovini, "Veselin Masleša", Sarajevo, 1967., str. 51.

25 I. Pederin, "Split u XV. stoljeću (I)", str. 266.

26 M. Šunjıć, "Postupni uspon", str. 12; Isti, Bosna i Venecija, str. 306.

27 I. Pederin, "Split u XV. stoljeću (I)", str. 244. 


\section{Svjedočanstva o crkvi i franjevačkom samostanu}

Crkvu i franjevački samostan u Veseloj Straži ne spominje nijedno nefranjevačko vrelo. Za razliku od crkve u $17 \mathrm{~km}$ udaljenoj Bistrici kod Gornjeg Vakufa/Uskoplja, ${ }^{28}$ nema im spomena ni u matičnim knjigama uskopaljskih katoličkih župa. Kapitul Bosanske franjevačke vikarije u crkvi u Veseloj Straži od 15. svibnja 1406. prvi se put spominje u krivotvorenoj povelji iz 16. st., koja se pripisuje vikaru te vikarije fra Marinu Splićaninu. U njoj je naznačeno da su se tadašnji i budući poglavari, kao i drugi franjevci te vikarije, prihvatili biti jamcima pravâ i posjedâ kneza Brajana Ohmčevića Grgurića, sinova mu Radivoja, Stipana i Radlava i njihovih nasljednika, koje im je tijekom kapitula potvrdio bosansko-humski kralj Ostoja (Prilog br. 1). ${ }^{29}$ U sažetoj formi prenio ju je 1892. godine i franjevački povjesničar Euzebije Fermendžin (1845.-1897.). ${ }^{30}$ Osim loše kompozicije i jezika kojim je napisana, na njezinu krivotvorenost upućuju i dva ključna elementa iz nje same: fra Marin Splićanin i kralj Ostoja. Naime, fra Marina Splićanina nema među poglavarima Bosanske franjevačke vikarije. ${ }^{31}$ Od 1405. do 1408. godine na njezinu je čelu bio fra Bar-

28 Ante Škegro, Libri mortuorum Parochiarum Scopiensium, "Hrvatski institut za povijest", Zagreb, 2012., str. 145, nr. 112; str. 150, nr. 319; str. 185, nr. 10, 17; str. 190, nr. 163, 178.

29 Codex Diplomaticvs Hungariae Ecclesiasticvs ac Civilis, Tomi X., Volvmen IV., Ab anno 1401-1409., Stvdio et opera Georgii Fejér bibliothecarii regii, "Typis typogr. Regiae Vniversitatis Vngaricae", Budae, 1841., str. 552-555, nr. CCLII.

30 Eusebius FermendžIn, Acta Bosnae potissimum Ecclesiastica cum insertis editorum documentorum regestis ab anno 925 usque ad annum 1752., Collegit et digessit P. Eusebius Fermendžin, "Academia Scientarum et Artium Slavorum Meridionalium", Zagrabiae, 1892., str. 80, nr. CCCCXXXVI. 1406. 15 Maii, Vesela Straža: Fr. Marinus a Spalato vicarius Bosnae ordinis s. Francisci commendat memoriae, "quomodo rex Ostoya de Bozna, considerando servitia, quibus servierunt praedecessores comitis Brajano Ohmuchevich Gargurich et specialiter vajvoda Granisav Ohmuchevich, pater denominati c. Brajani, tum suis praedecessoribus quam sibi, nec non ipse comes Brajano et eius filii Radivoj, Stephanus et Radlav", "transeunte heri aula per istum locum Vesela Straža intravit ecclesiam et facta oratione praedictus rex Ostoja et cum illo comes Brajano venit ad nos ad capitulum", ubi dictum c. Brajanum cum filiis "propter illorum fidelia servitia tempore, quo me expulit Bozna, quo in sola civitate Bobovaz detinebar", concredidit protectioni ecclesiae una cum illius bonis et possessionibus.

31 Dominik Mandić, "Franjevačka Bosna. Razvoj i uprava Bosanske Vikarije i Provincije 1340.-1735.", u: Dominik Mandić, Sabrana djela, sv. III., "Her- 
tul Alvernski. ${ }^{32}$ Povlastice i posjede Brajanu Ohmučeviću Grguriću, njegovim sinovima i njihovim nasljednicima, nije mogao potvrditi kralj Ostoja (1398.-1404.; 1409.-1418.) jer je u vrijeme tobožnjeg održavanja ovoga kapitula bosansko-humskim kraljem bio Tvrtko II. Tvrtković (1404.-1409.; 1421.-1443.). ${ }^{33}$ Inicijator nastanka ove povelje mogao je biti Ivelja Ohmučević - imućni glavar Ohmučevićâ iz Slanoga kod Dubrovnika, pred Osmanlijama u to mjesto izbjeglih iz Popova i Orahova u istočnoj Hercegovini. ${ }^{34}$ Vjerojatnije je, ipak, da je to bio njegov sin i admiral španjolskog kralja Filipa II. (1556.-1598.) don Pedro de Iveglia Ohmuchievich Gargurich, koji se i na taj način nastojao dokopati plemićke časti. ${ }^{35}$ Inicirao je i izradu tzv. KorjenićNeorićevog grbovnika, čiji najstariji prijepis datira iz 1595. godine. ${ }^{36}$ Nakon neuspjeha u Dubrovniku 1584. i 1588. godine, don Pedro se plemstva domogao 1596. godine u Španjolskoj. ${ }^{37}$ Krivotvoriteljem ove povelje smatra se prijatelj Ohmučevićâ Grgurićâ iz Slanoga fra Beno Orsini, koji je bio i autor prijepisa spomenutog grbovnika. ${ }^{38}$

Samostan u Veseloj prvi od franjevačkih kroničara spominje fra Andrija Šipračić (+1698.) u svojoj kronici ${ }^{39}$ koju je počeo pisati 1684. godine nakon što mu je istekla služba provincijala Franjevačke Pro-

cegovačka franjevačka provincija Uznesenja BDM" - "FRAM Ziral", Mostar, 2013., str. 411-617.

32 D. Mandić, "Franjevačka Bosna", str. 489.

33 Pavo Žıvković, Tvrtko II. Tvrtković, "Institut za istoriju u Sarajevu", Sarajevo, 1981., pass; Dubravko Lovrenović, Na klizištu povijesti (sveta kruna ugarska i sveta kruna bosanska) 1387-1463, "Synopsis", Zagreb - Sarajevo, 2006., str. 114 i pass.

34 Ivo BANAc, Grbovi biljezi identiteta, "Grafički zavod Hrvatske", Zagreb, 1991., str. 12.

35 I. BANAC, Grbovi, str. 12.

36 I. BAnAC, Grbovi, str. 133; STJEPAN Ćosić, Ideologija rodoslovlja: KorjenićNeorićev grbovnik iz 1595., "Zavod za povijesne znanosti HAZU u Dubrovniku", Dubrovnik - Zagreb, 2015., pass.

37 Antun Golušıć, Rodovi Slanskog primorja, "Zavod za povijesne znanosti Hrvatske Akademije Znanosti i Umjetnosti u Dubrovniku", Dubrovnik, 1991., str. 56-57; I. BANAC, Grbovi, str. 13.

38 I. BANAC, Grbovi, str. 13.

39 Stjepan Duvnjak, "Bosanički rukopisi u knjižnici Franjevačkog samostana u Kraljevoj Sutjesci", u: Filologija: časopis Razreda za filološke znanosti Hrvatske akademije znanosti i umjetnosti Zagreb, br. 63, Zagreb, 2014., str. 95-96: "Tabula od ministara, i Kapitula, koise mogu znati, koisu bili uovoi 
vincije Bosne Srebrene. ${ }^{40} \mathrm{U}$ njoj se govori i o održavanju franjevačkog kapitula u samostanu u Veseloj 15. svibnja 1406. kao i o potvrdi privilegija knezovima Ohmućevićima i njihovim nasljednicima od strane kralja Ostoje tijekom održavanja samoga kapitula te bosanskim franjevcima kao jamcima. ${ }^{41} \mathrm{U}$ svome Ljetopisu iste ove podatke prenosi i fra Nikola Lašvanin-Marčinkušić (1703.-1750.). ${ }^{42} \mathrm{O}$ franjevačkom samostanu u Veseloj Straži kao o povijesnoj činjenici piše i fra Filip Lastrić (1700.-1783.) u svome Pregledu starina bosanske provincije. ${ }^{43}$ Zidine franjevačkoga samostana u Veseloj Straži 1847. godi-

Provincii Bosne arćentine, i šose dogodilo za koga Ministra, iod druzie Stvari, i dekreta, carkovnie."

40 D. Mandić, "Franjevačka Bosna", str. 584-585.

41 "Tabula od ministara, i Kapitula, koise mogu znati, koisu bili uovoi Provincii Bosne arćentine, i šose dogodilo za koga Ministra, iod druzie Stvari, i dekreta, carkovnie; početo pisati pomeni Fra Andrii Šipračiću roda očina, a Margaritiću roda Materina, iz Dubočca, župe Sutiške actualomu, aliti sadanemu Ministru, iste prov[inci]e na $\underline{1684}$. reko na 1684 . Miseca ruina na 3. reko miseca sett $[\mathrm{em}]$ bra: na $\underline{4}$. četvarte godine Svoga Ministrata, zaš $[\mathrm{t}] \mathrm{o}$ navarših trienio na 14. jula prošastoga, iste ove godine: ukreševu umanastiru Svete Kate: 'Na 1406. reko na 1406. 1406. na 15. svibnja budući bio Manastir uskopiu uveseloj gdie tada činjen kapito, i bioe vikar proviciali o. f. Marin Splićanin, vikar od Sve bosne, koi Svidoči kako u oni kapito dođe kralj ostoia ter onde potvardi sva privileđia kuće ohmućevića koisu Koisu bili Konti, aliti knezoovi od tugelja kod saraeva, od Smutske carne rike, i druzie zemalj među neretvom, i Kreševom, iučini onde u kapitolu, fratre one iste došaste uprovincii bosanskoj da imaiu odit zaštitetilji, i branioci rečenie privileđia."'

42 Nikola Lašvanin, Ljetopis. Priredio, latinske i talijanske dijelove preveo, uvod i bilješke napisao dr. fra Ignacije Gavran, "Synopsis", Sarajevo - Zagreb, 2003., str. 251: "Na 1406. Budući bio man(asti)r u Skopju, u Veseloj Straži, gdi je tada činjen kapitô, i bio je vikar provincijali od sve Bosne f(ra) Marin Splićanin, koji svidoči, kako u oni kapitô dođe kralj Ostoja, ter onde potvrdi sva privileđija kuće Ohmućevića, koji su bili konti, al(i)ti knezovi od Turelja kod Sarajeva, od Smuske, Crne Rike i drugijeh zemalja među Neretvom i Kreševom. I učini onde fratre one i sve došaste u provinciji bosanskoj, da imadu biti zaštititelji i branioci rečenih privileđija."

43 Filip LAstrić, Pregled starina Bosanske provincije. Bilingvalno izdanje. Priredio, uvod i komentare napisao dr. fra Andrija Zirdum. S latinskoga i talijanskoga preveli dr. fra Ignacije Gavran i fra Šimun Šimić, "Synopsis", Sarajevo - Zagreb, 2003., str. 120: "Razrušeni, spaljeni i napušteni samostani otkad je porobljena Bosna počela uzdisati o njezinim se uzdasima ne nazire kraja. Prvi je samostan bio u Milima ili Miloševu. Sagradio ga je ban Stjepan; u njemu je on i pokopan. Drugi je bio u Veseloj Straži kod Skoplja. U njemu je bosanski kralj Ostoja počastio svojom nazočnošću provincijsku skupštinu braće godine 1406, kako čitamo u rukopisnim kodeksima fojničkog samo- 
ne spominje fra Ivan Franjo Jukić (1818.-1857.), ne precizirajući gdje su se nalazili niti po čemu su mu bili prepoznatljivi. ${ }^{44}$ Jukićevo svjedočenje o tome samostanu preuzeo je 1878. godine Vjekoslav Klaić (1849.-1928.). ${ }^{45}$ Nakon toga stručna literatura uglavnom ne dvoji oko postojanja ovoga samostana. ${ }^{46}$

\section{Pustošenje objekta na Crkvinama prije arheoloških iskopavanja}

Veselu Stražu, njezino podgrađe i okolicu 70-ih godina 19. stoljeća devastirao je mjesni feudalac Ali-beg Sulejmanpašić. ${ }^{47}$ Same, pak, Crkvine razarane su u više navrata. ${ }^{48}$ Prekopavane su i 1910. tijekom

stana." Isto, str. 126: 8. 1405. o. Marin (prema drugima Martin) Splićanin. Ovoga nema u popisu o. Vinka Blahe. Ali, za mene je to sigurno iz rukopisa o. Andrije iz Dubočca: u njegovom ljetopisu čitam slijedeći tekst na ilirskom, koji prevodim na latinski: "Godine 1406, 16. svibnja u Skoplju, u Veseloj, gdje je tada bio kapitul, bio je i provincijski vikar o. Marin Splićanin, vikar cijele Bosne; on svjedoči da je na taj kapitul došao kralj Ostoja..."

44 Ivan Franjo Jukić, Sabrana djela. Knjiga I, Svjetlost, Sarajevo, 1973., str. 71: "Poslije tri dni krenem se iz Malog Sela put Kupresa, i za jedan sat stigosmo u vrlo prijatno mjesto Vesela Straža; ovdje se vide i sad zidine bivšeg negda franciškanskog samostana." Isto, str. 197: "Vesela Straža, lijepo selo turskokrstjansko, gdje su odžaci više begovah, i skoro sagrađen Pašića miri-alaja; ovdje se vide zidine od srušenog franciskanskog samostana."

45 Vjekoslav Klaić, Bosna. (Zemljopis.). Sabrao i poredao Vjekoslav Klaić, "Matica hrvatska", Zagreb, 1878., str. 163: "Vesela straža, liepo selo muhamedovsko-katoličko, gdje su odžaci mnogih begova; ovdje se vide zidine srušenog samostana franjevačkog."

46 Д. Ковачевић-Којић, Градска насеља, str. 126; PAvaо AnĐelić, "Vesela Straža", u: Arheološki leksikon Bosne i Hercegovine, Tom 2. "Zemaljski muzej Bosne i Hercegovine", Sarajevo, 1988., str. 187, nr. 12.257; ANDRIJA Zirdum, Povijest kršćanstva u Bosni i Hercegovini, "Slovoznak", Plehan, 2007., str. 204, 207, bilj. 411; Ante ŠKegro, Uskoplje I. Uskoplje na Vrbasu od prapovijesti do kraja austro-ugarske uprave, "Hrvatska uzdanica", Uskoplje, 1996., str. 57, 80-81; Isti, Libri mortuorum, str. XXI-XXII.

47 O ovome feudalcu: Husnija Kamberović, Begovski zemljišni posjedi u Bosni i Hercegovini od 1878. do 1918. godine, "Hrvatski institut za povijest" - "Institut za istoriju", Zagreb - Sarajevo, 2003., str. 452-453.

48 Поп М. Чавић, "Општина 'Весела Стража'", Дабро-босански Источник: лист за црквено-просвјетне потребе српско-православног свештенства у Босни и Херцеговини, год. II, бр. 11 и 12 (17 и 18) Сарајево, новембар и децембар 1888., str. 193: "Има нека старина, двије градине и једна више села $1 / 4$ сахата заузима. Около велике куле ограда са зидом. Простора око 300 ока усјева јечма јечма-земљишта. Кула има око 40 аршина 
gradnje akumulacijskoga jezera za hidrocentralu koja je Bugojno opskrbljivala strujom. Nema dokazâ da je tom prilikom pronađen i u rukama neimenovanog austro-ugarskog predradnika završio i jedan kalež. ${ }^{49}$ Crkvine su devastirane i 1936./1937. godine, tijekom gradnje hidrocentrale bankara Mauricija Stappa. ${ }^{50} \mathrm{U}$ okviru znanstveno-istraživačkoga projekta sarajevskog Zavoda za zaštitu spomenika kulture, prirodnih znamenitosti i rijetkosti Bosne i Hercegovine "Uskoplje u srednjem vijeku i ranom turskom periodu (do 17. stoljeća) s posebnim osvrtom na utvrđene gradove Vesela Straža, Susjedgrad i Prusac" sondažna iskopavanja na Crkvinama izveli su 1982. godine arheolozi Đorđo Odavić iz Muzeja Hercegovine Trebinje i Ivanka Ribarević iz Muzeja Hercegovine Mostar. ${ }^{51}$ Tom su prilikom otkopani

начетврт са дебелим зидом око 2 метра. И сада пушкарнице се знаду са некијех страна. Натраг 15 година ниже града - више села, копао је Алибег Сулејман Пашић за куће камен. И причају да је ископао доста копаља, ковао од њих ексере. А чобани су нашли у зиду забодено једно од топа зрно и причају да је у граду стајао Озринић. У граду је било више кућа. Према томе граду удаљено $1 / 2$ сата стоји други град. Идући западу около њега је била ограда около 150 ока усјева. Град је око 20 аршина начетврт; о мањег града управ великом тече издаљег ријека Прешљаница, и ниже већег града утјече у ријеку Весхицу. Између градова са двије стране Прешљанице стоје двије мале зидине (два мала зидића и причају да су биле ту страже за варош, која је била около Прешљанице. На једној равници ниже мањег града зове се једно мјесто Црквина, обрасло малом шумом, право окренуто истоку; има доста и камена обраслог. И народ тражећи новаца, копао је на више мјеста. Дугачка је около 35 аршина а широка 20 аршина и говоре да је православна. Около обадва града од неки страна били су опкопи."

49 Pismena izjava Vlade Šistova (rođ. 17. 6. 1966.), sina Filipa Pilke Šistova, iz Vesele kod Bugojna: "Kao dječaku od nekih 12-13 godina moja baba Janja mi je pričala da je moj dedo a njen muž Markan Šistov radio na izgradnji Austrougarske HE-Bugojno na izgradnji vodozahvata na zemljištu Crkvini. Baba mi je pričala da su našli kalež te da su ga predali sefu radilišta. Isto tako je rekao da su dobili nagradu da ta priča ne ide dalje i da se šuti o tom danu. Poznajući naš mentalitet bilo je logično da će se on povjeriti svojoj suprugi."

50 Drago Miličević, "5. Rijeke Bugojna", u: Bugojno ispod Kalina i Rudine zbornik, "Z. Cukalo", Zagreb, 2012., str. 51; Isti, "7. Stanovništvo općine Bugojno i njegove suvremene transformacije", u: Bugojno ispod Kalina, str. 67.

51 Rukopisna ostavština mr. sc. Drage Miličevića list br. 69d: "Dodati tekst za Kik Kako sam istakao u ljeto 1982 godine, grupa arheologa iz Sarajeva, istraživala je i Kik. Grupu su sačinjavali Ivanka Ribarević i Djordje Odović (sic!). Grupa konstatira da je grad nepristupačan. Konstatirano je da je i Veselu stražu spomenuo Pop Dukljanin u 12 stoljeću, a i podatak da su ga zauzeli Turci 1478. godine. Grad je imao formu izduženog pravokutnika, sa dimen- 
i zidovi s freskama. ${ }^{52}$ Svjedočenje o ovome iskopavanju sačuvalo se u neobjavljenim bilješkama profesora bugojanske gimnazije Drage Miličevića (1927.-2000.). ${ }^{53}$ Crkvine su prekapane i 2006. godine tijekom gradnje akumulacijskog jezera i kaptaže za hidroelektrane "Pršljanica 1" i "Pršljanica 2" u Veseloj kod Bugojna.

zijama $(24,25+19,5)=43,75$ metara, na istok. Širina jedne strane je 9,95 a paralelne strane 5,60 metara. Cjela dužina je bila podjeljena zidom dužine 9,00 metara na dvije prostorije. Otkriveni su zidovi visine 2,35 m. Prostor grada je na Kiku slabije očuvan od onoga dijela na Gradecu. U iskopanom dijelu, od arheološkog materijala nadjeno je dosta slovenske keramike sa tordiranim užetom, te jedan slovenski nož kao i kameno topovsko djule."

52 ĐorĐo Odavić, "Biograd, Prusac srednjovjekovni grad", u: Arheološki pregled, br. 25, Beograd, 1986., str. 78. Usmeno svjedočenje člana toga istraživačkog projekta dr. sc. Zdenka Žeravice (1945.-2010.) iz sarajevskoga Zavoda za zaštitu spomenika kulture i prirodnih rijetkosti Bosne i Hercegovine. Usp. A. ŠKegro, Libri mortuorum, str. XXII.

53 Rukopisna ostavština mr. sc. Drage Miličevića list br. 52: "dodati 29b Đ. Odavić, I. Ribarević Crkvina Lokalitet se nalazi na desnoj strani puta od Vesele do Pršljana. Nalazi se na nasipu koji je obrastao drvećem, a potok Pršljanica prolazi kroz lokalitet. Gradjevina je napravljena od lijepo tesanog kvadera sadre (Travertina) Nadjeno je nešto bojenog maltera Zgrada je imala dvoja vrata jedna sa istočne a druga sa zapadne strane. Karakteristično je da su vrata sa istočne strane bila široka $1,40 \mathrm{~m}$, a zapadna su bila široka 2,25 m. Ulazi na oba vrata su popločani kamenim pločama. Zidovi su prilično široki tako da je pored istočnog ulaza zid širok $1,35 \mathrm{~m}$. Širina zgrade je $8,20 \mathrm{~m}$, dok je dužina $30,6 \mathrm{~m}$. Na dužini se ističe još dio zida prema sjeveru i jugu, tako da se njime može dijeliti dužina objekta na dva dijela i to onaj zapadni je dug 16,20 m. a istočni 14,40 m." List br. 52 (71a): "Za lokalitet Crkvina dodati nalazi se na desnoj strani Pršljanice. Nalazi se pokraj istoimenog potoka a izmedju njega i puta na aluvijalnom dijelu nanosu Pršljanice. Zgrada je zidana od pravilnih kvadera travertina (sedre). Na zidu su nadjeni fragmenti boje smedje i crvene. Evo i dimenzija, na zapadnoj strani je iskopan zid dug 3,40 $\mathrm{m}$ sa vratima širokim $2,25 \mathrm{~m}$ i daljim dijelom zida dužine 3,70 m. Dakle ukupna dužina zida je 9,35 metara. Suprotno ovoj strani je strana prema istoku gdje je otkriven zid dužine 8,20 metara, a zatim još van zgrade dug 4,0 m. Sjeverni zid je dug $8,37 \mathrm{~m}(4,10 \times 1,1 \times 3,17)$. To je nepotpun dio zida jer ga je rijeka znatno erodirala. Južni zid je cjelovitiji te mu je dužina 30,6 metara $(16,2=14,40)$. Vrijedi istaći i dimenzije vrata, sa istočne strane bila su visoka $1,40 \mathrm{~m}$. Zapadna vrata su bila široka 2,25 metara. Širina zidova ovog objekta je $1,35 \mathrm{~m}$. Prostor oko ističnih (sic!) i zapadnih vrata je bio popložan (sic!) kamenim pločama. Evo i otkopanog tlocrta objekta sakralnog objekta CRKVINA." 


\section{Arheološka iskopavanja 2014. godine}

Prije početka prve faze arheoloških iskopavanja, koja je trajala od 10. do 20. prosinca 2014., vlasnik zemljišta ${ }^{54}$ teškom je mehanizacijom uklonio površinski sloj s objekta na Crkvinama. ${ }^{55}$ Teška mehanizacija devastirala je ovaj objekt i nekoliko godina ranije, tijekom postavljanja sustava odvodnje iz akumulacijskog jezera koje je zahvatilo i njegovu sjevernu te zapadnu stranu. Teška mehanizacija korištena je i tijekom samih arheoloških iskopavanja. ${ }^{56}$ To je za posljedicu imalo radikalni poremećaj kulturnih slojeva, zbog čega se nije mogla utvrditi ni visina zidova ovoga objekta. Tijekom ove faze iskopavanja uza sjeverni zid srednje prostorije ispod šuta pronađeni su dovratnici (sl. 1) i ulomci dovratnikâ i nadvratnikâ (sl. 2). Prethodno je vlasnik zemljišta na kojem se Crkvine nalaze došao do većeg broja ulomaka dovratnikâ (sl. 3) i nadvratnikâ, oblikâ i ukrasâ identičnih prethodnima (sl. 4) te ulomka kamene posude (sl. 5). Ulomak kamene baze stupa (sl. 6) izronio je iz nasipa akumulacijskog jezera uz unutarnju stranu istočnog ulaza u sjevernu prostoriju. Freske od nejednakih crveno-bijelih pravokutnika oivičenih tamno-plavom vrpcom zatečene su po cijelom zidu od istočnog ulaza u sjevernu prostoriju do ulaza iz sjeverne u srednju prostoriju kao i po istočnoj strani toga ulaza. Na toj strani ulaza, između crveno oslikanih pravokutnika, zatečen je i istokraki križ od bijelih pravokutnika sa svjetlo-zelenim kvadratom u središtu (sl. 7). Prethodno je vlasnik zemljišta na kojem se Crkvine nalaze došao i do ulomka freske s identičnim motivom (sl. 8). Suprotna strana ovoga ulaza nije bila oslikana, ali su na nanesenom malteru bili ucrtani pravokutnici dimenzija sličnih onima na suprotnoj oslikanoj strani (sl. 9). Iz toga proizlazi da oslikavanje ovoga objekta nije dovršeno. Da ni u građevinskom smislu nije bio završen, naslućuje se iz toga što su tragovi krova i čavli kojima je bio učvršćen pronađeni samo u sjevernoj oslikanoj prostoriji. Nepovoljne klimatske prilike tijekom ove faze iskopavanja te neadekvatna

54 K. č. 2170/1, K. o. Vesela, Bugojno, vlasništvo lokalnog poduzetnika Huseina Smajića iz Vesele kod Bugojna.

55 Prof. dr. sc. Ante Škegro iskopavanja je pratio temeljem pismenog poziva Huseina Smajića.

56 Zavičajni muzej Travnik zbog teške mehanizacije korištene tijekom iskopavanja, odustao je od iskopavanja objekta na Crkvinama u Veseloj kod Bugojna. Vlasnik zemljišta za daljnja je iskopavanje angažirao djelatnike Franjevačkog muzeja u Tomislavgradu "Fra Jozo Križić" (Ljubo Oreč, Krunoslava Oreč, Nikša Grbić). 
zaštita rezultirali su trenutnom propašću najvećeg dijela freski. Nakon uklanjanja nasipa i šuta postalo je jasno da se ovaj objekt $(26,8 \mathrm{x}$ $21,40 \mathrm{~m}$ ) sastojao od tri prostorije različite debljine zidova. U njega se ulazilo kroz dvoja vrata na istočnoj i zapadnoj strani sjeverne prostorije, iz koje se kroz jedna vrata ulazilo u srednju prostoriju (sl. 10). ${ }^{57}$ Uklanjanjem nasipa i šuta otkopan je zid između sjeverne i srednje prostorije, za kojeg je utvrđeno da je širok 2, a na nekim mjestima viši i od $2 \mathrm{~m}$ (sl. 11). Sjeverni zid kao i istočni i zapadni kutovi sjeverne prostorije u cijelosti su nedostajali. Očito su bili uklonjeni tijekom gradnje akumulacijskog jezera, koje je zahvatilo upravo te dijelove ovoga objekta. Slijedilo je otkopavanje vanjskog zida južne prostorije, čija najveća visina nije prelazila $0,7 \mathrm{~m}$ dok $\mathrm{mu}$ je širina iznosila oko $1,15 \mathrm{~m}$ (sl. 12). Vanjske su mu strane, kao i zida između sjeverne i srednje prostorije, građene od precizno oklesanih sedrenih blokova. Prostor između sedrenih blokova popunjen je lomljenim vapnencem vezanim obilnim količinama vrlo kvalitetnog maltera. Dimenzije ostalih zidova bile su različite kako u širini tako i u visini. Temeljni zidovi ovoga objekta položeni su na lomljeni vapnenac različitih dimenzija. Na zapadnoj strani objekta, uz vanjsku stranu zida koji dijeli srednju i južnu prostoriju, nalazila se grobnica $(2,05 \times 2,25 \mathrm{~m}) \mathrm{s}$ ljudskim skeletima (sl. 13).

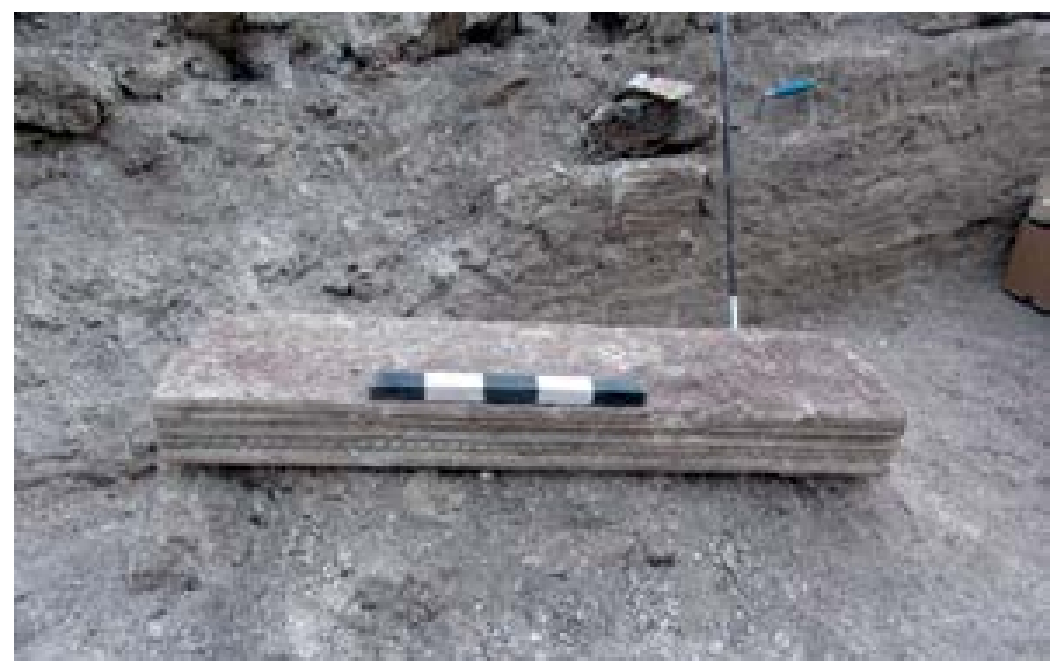

Sl. 1. Dovratnik iz srednje prostorije Fig. 1. Door-post from the central room

57 Širina istočnih vrata: $1,40 \mathrm{~m}$; širina zapadnih vrata: $1,55 \mathrm{~m}$; širina vrata iz južne u srednju prostoriju: $1,05 \mathrm{~m}$. 


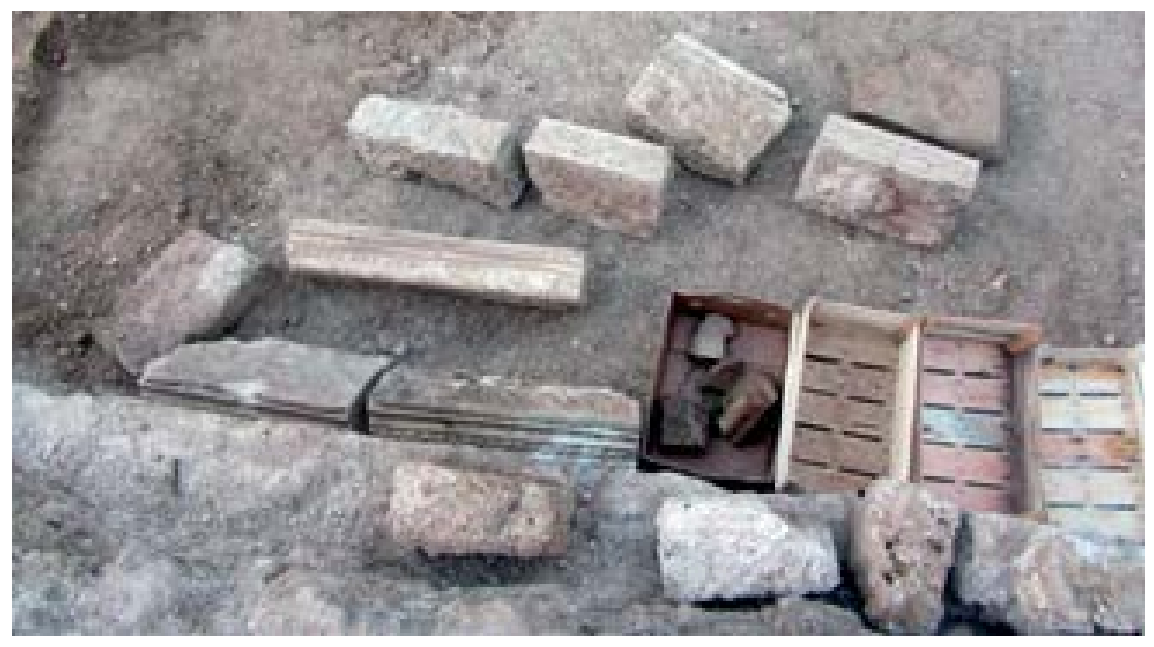

S1. 2. Ulomci dovratnikâ i nadvratnikâ iz srednje prostorije Fig. 2. Fragments of door-posts and lintels from the central room

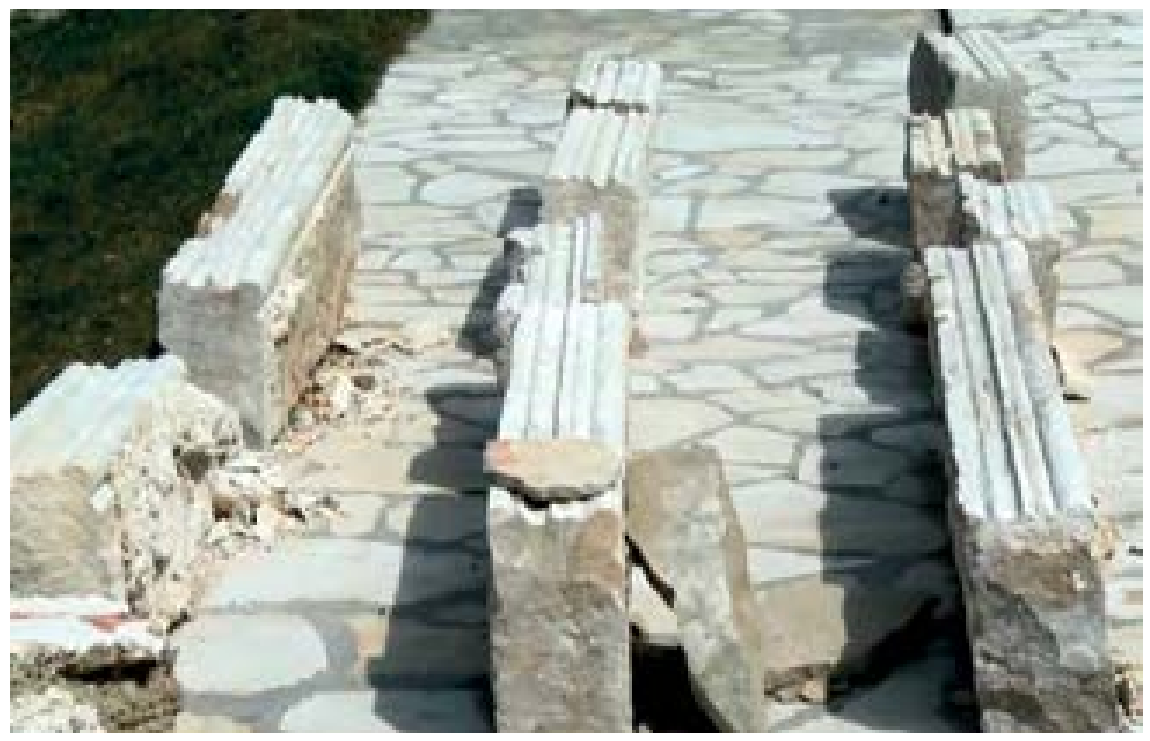

Sl. 3. Ulomci dovratnikâ izvađenih prije istraživanja Fig. 3. Fragments of door-posts pulled out before the excavations 


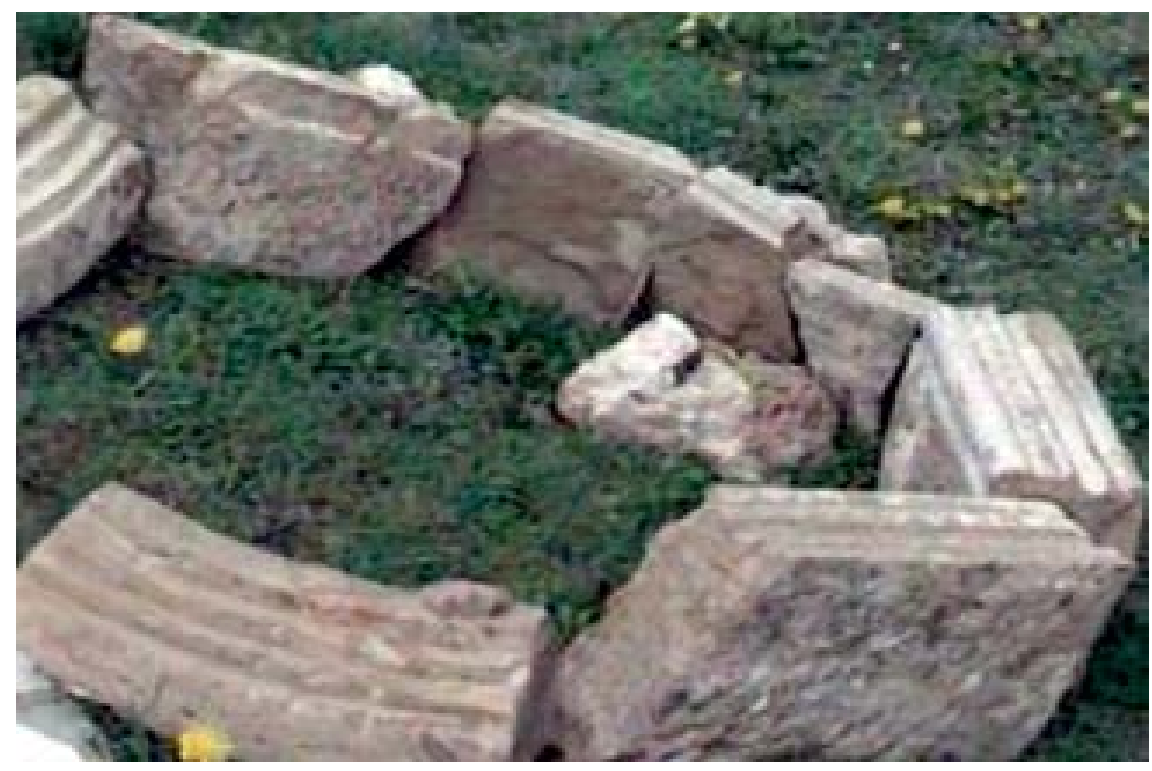

Sl. 4. Ulomci nadvratnikâ i dovratnikâ izvađenih prije arheoloških istraživanja Fig. 4. Fragments of lintels and door-posts pulled out before the archaeological excavations

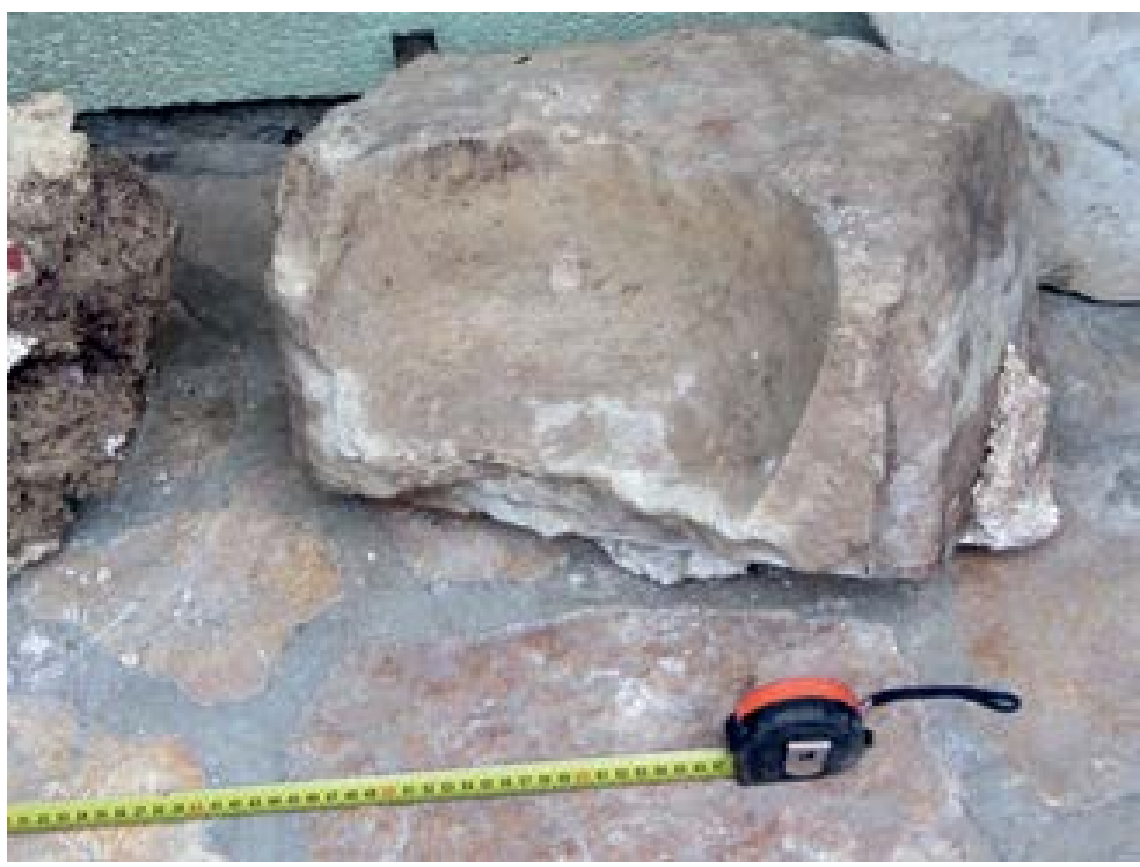

S1. 5. Ulomak kamene zdjele Fig. 5. Fragment of a stone jar 


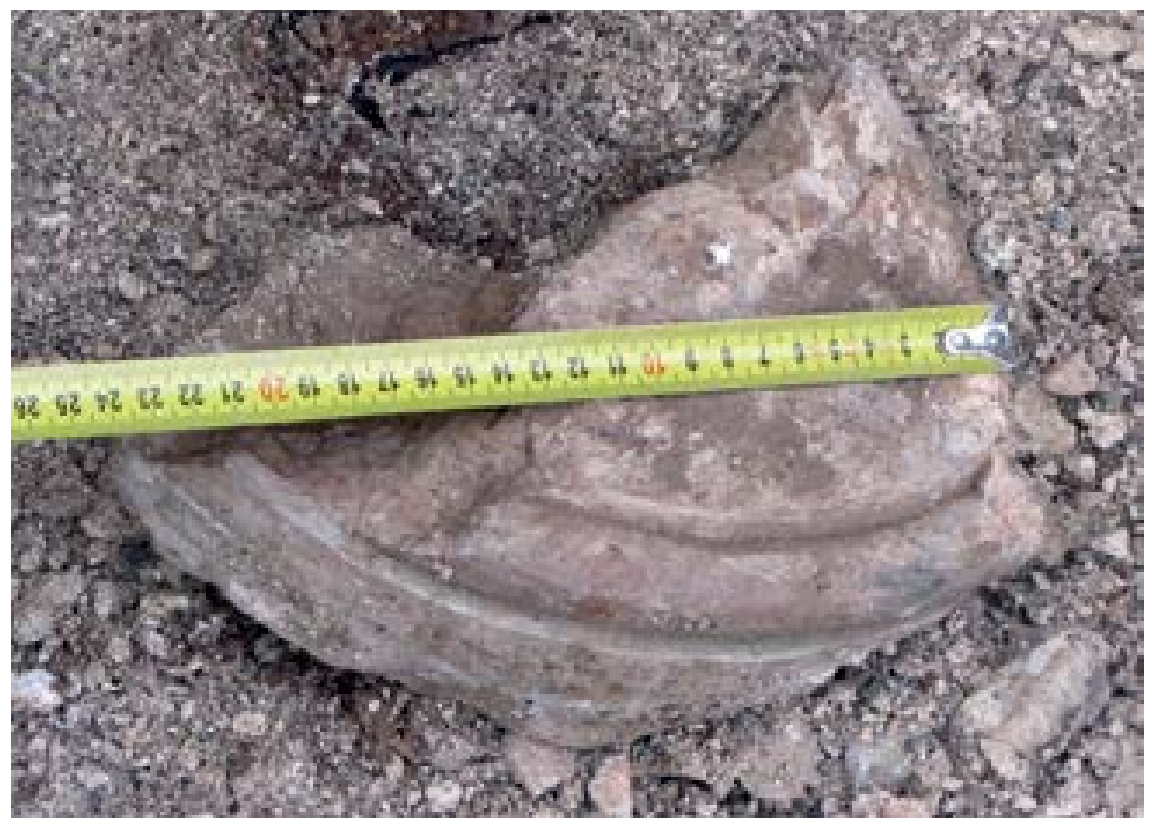

Sl. 6. Ulomak baze stupa

Fig. 6. Fragment of a colonnade basis

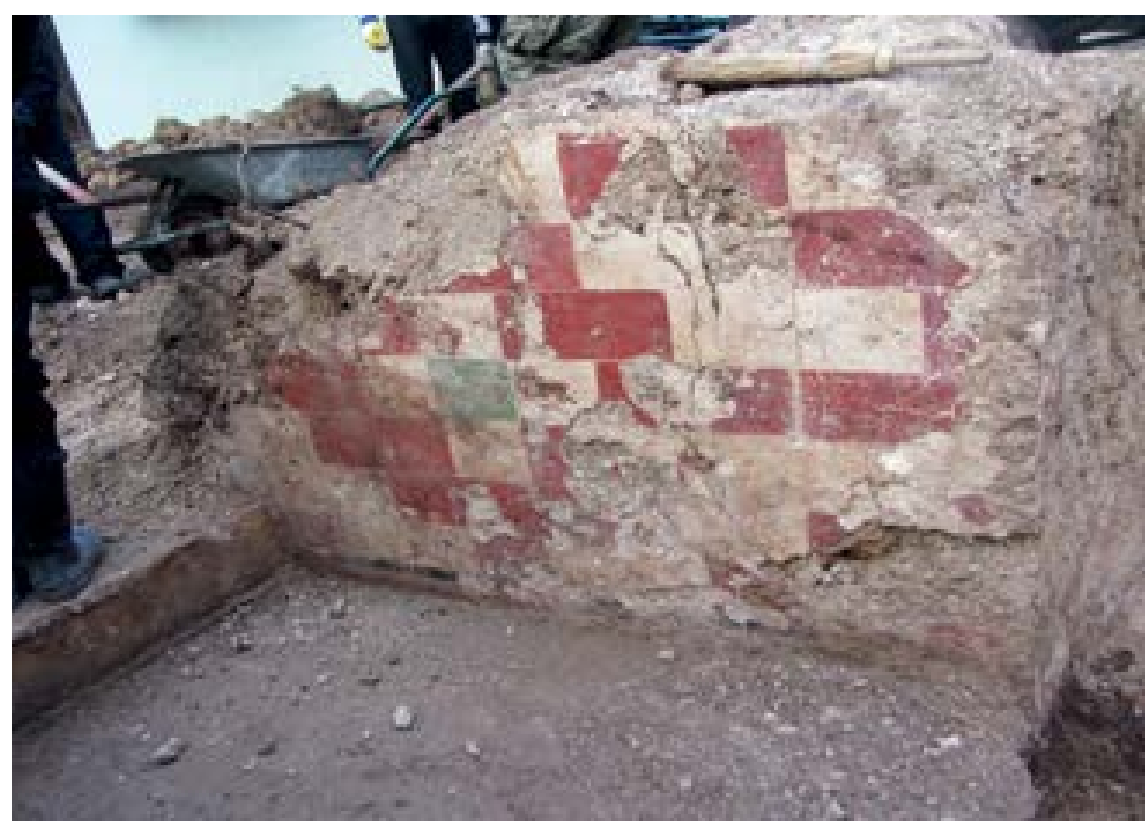

S1. 7. Freska na istočnoj strani ulaza iz sjeverne u srednju prostoriju Fig. 7. Frescoes on the east side of the entrance from the north to the middle room 


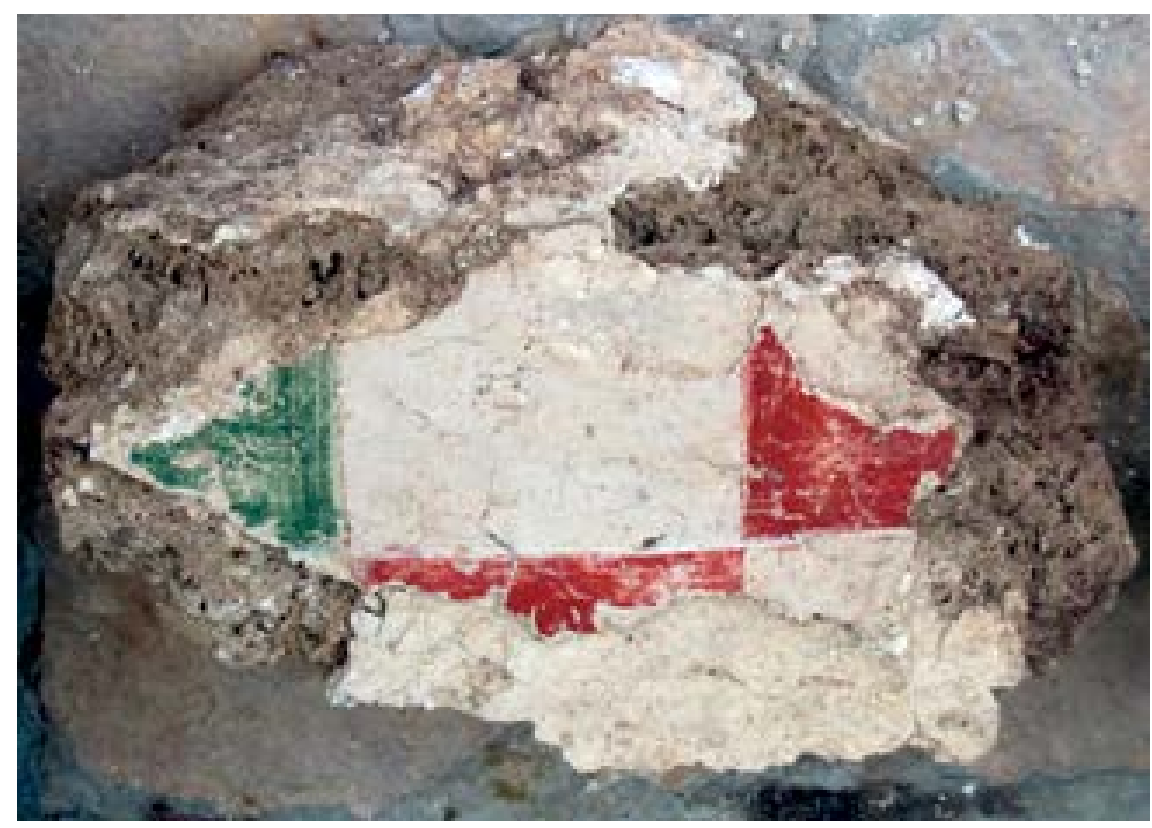

S1. 8. Ulomak freske s plavozelenim kvadratom Fig. 8. Fragment of the fresco with the blue-green square

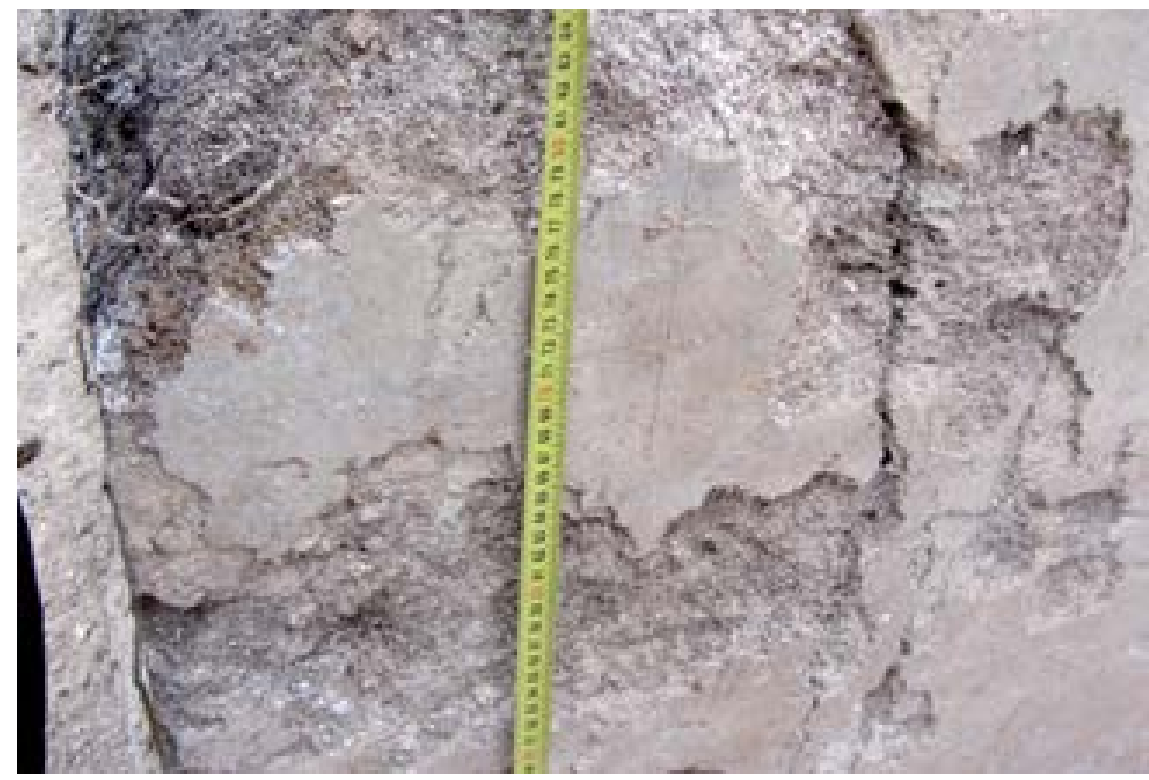

S1. 9. Ucrtani pravokutnici na zapadnom dijelu ulaza iz južne u srednju prostoriju Fig. 9. Drawn rectangles on the western side of the entrance from the southern to the central room 


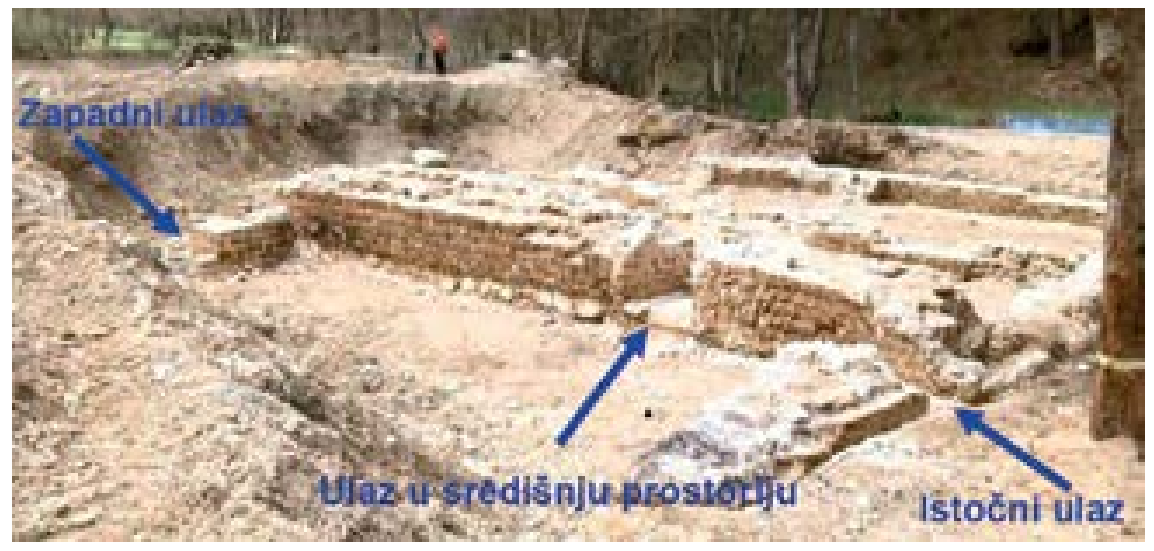

Sl. 10. Ulaz iz sjeverne u srednju prostoriju Fig. 10. Entrance from the north to the central room

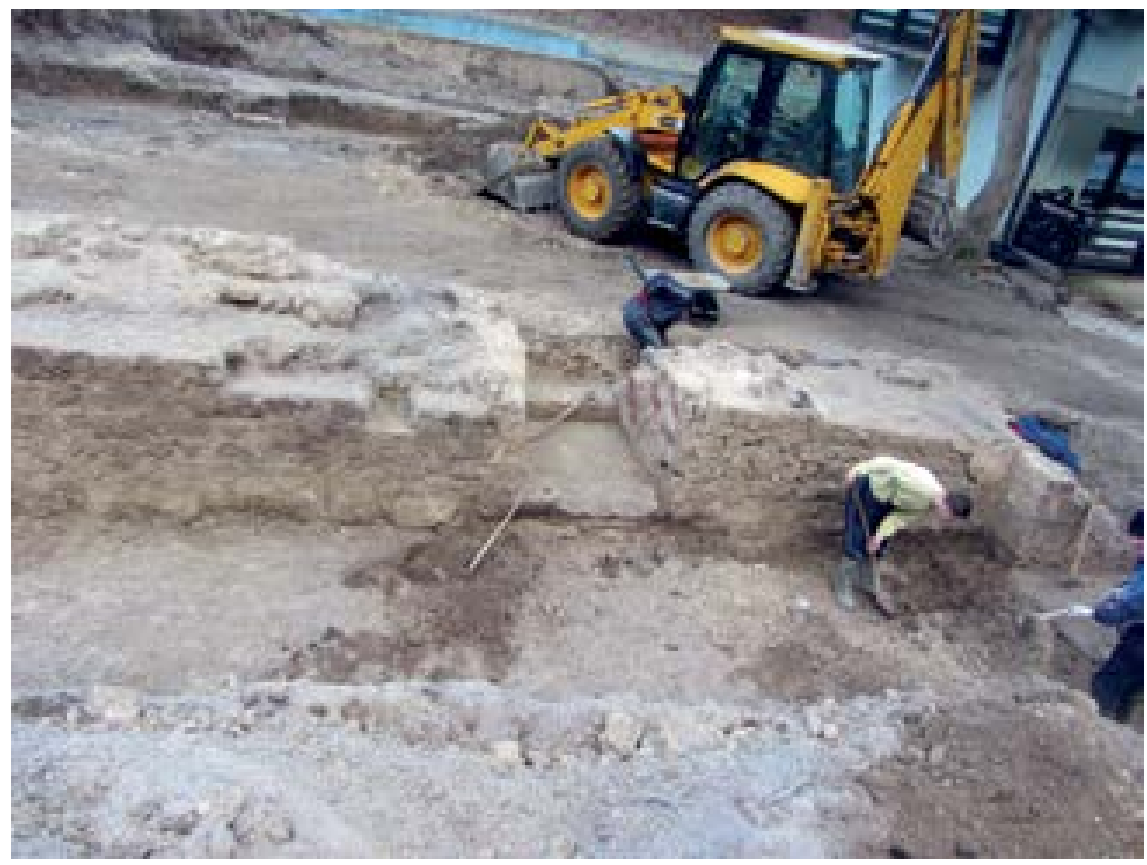

Sl. 11. Otkopavanje zida između sjeverne i srednje prostorije Fig. 11. Excavation of a wall between thenorth and central room 


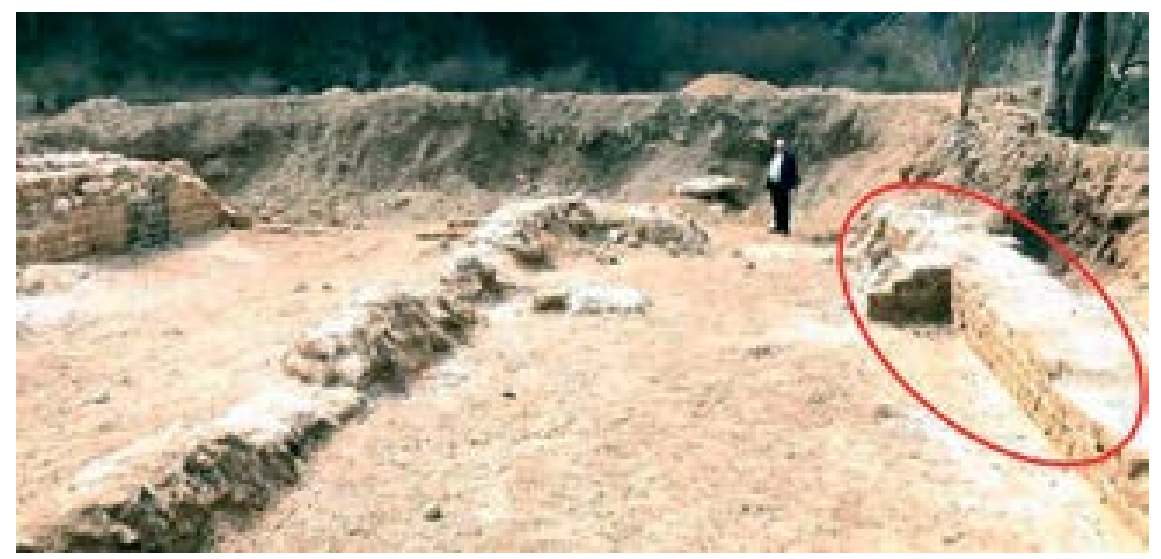

S1. 12. Segment južnog zida južne prostorije Fig. 12. Part of the south wall of the south room

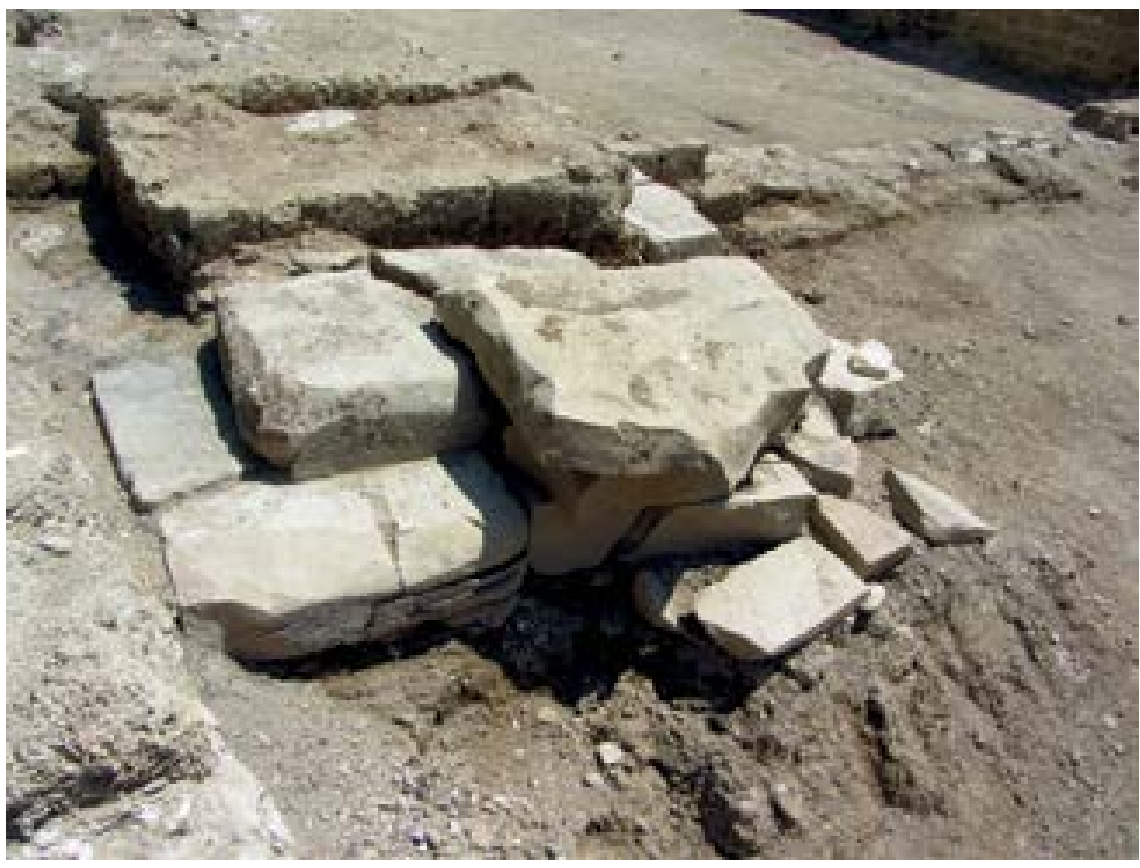

S1. 13. Grobnica pokraj zida koji dijeli srednju od južne prostorije Fig. 13. Tomb along the wall that separates the middle and south room 


\section{Arheološka iskopavanja 2015. godine}

Nakon što je vlasnik zemljišta prije druge faze iskopavanja, koja je trajala od 8. do 14. lipnja 2015., bez nadzora uklonio nasip akumulacijskog jezera, uza zapadnu stranu objekta ukazali su se tragovi izdužene građevine (16 x 10 m). Oblik i konstrukcija, ali i okolnosti pojave ne govore u prilog njezinoj autentičnosti (sl. 14), baš kao i manipuliranje srednjovjekovnim nadgrobnicima unutar i oko toga objekta (sl. 15.). Uz južnu stranu sjevernog zida južne prostorije, u nivou ispod temelja, pronađen je ulomak svijetlo-žute keramike (sl. 16) i fragment majolike (sl. 17). U sjevernoj prostoriji zatečeni su tragovi spaljenog krova s desetak kovanih željenih čavala različitih dimenzija. U sjeverozapadnom kutu središnje prostorije naišlo se na ljudski kostur (sl. 18) i bedrenu kost odrasle osobe s omanjim svitkom olovnog lima (sl. 19). Uslijedio je pronalazak dječjih skeleta uza zapadni zid objekta, pohranjenih u običnoj grobnoj raki.

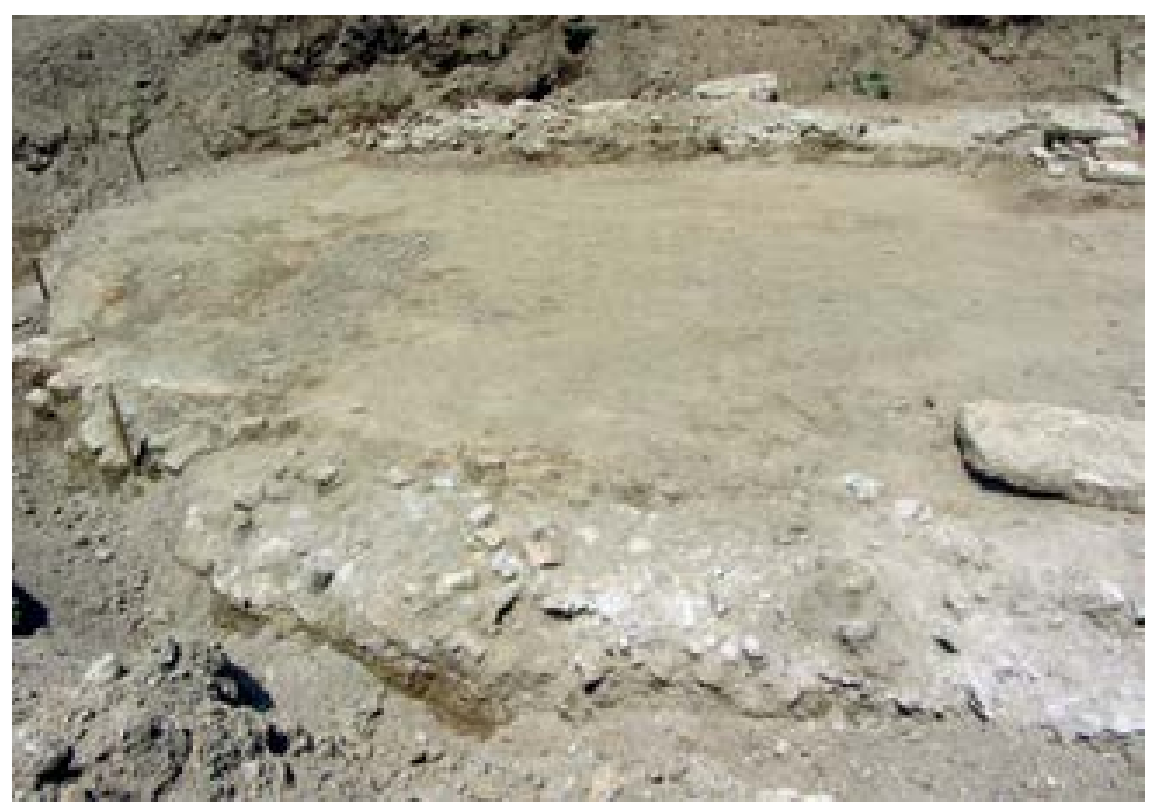

S1. 14. Tragovi građevine uza zapadnu stranu objekta na Crkvinama Fig. 14. Traces of the object by the west side of the building at Crkvine 


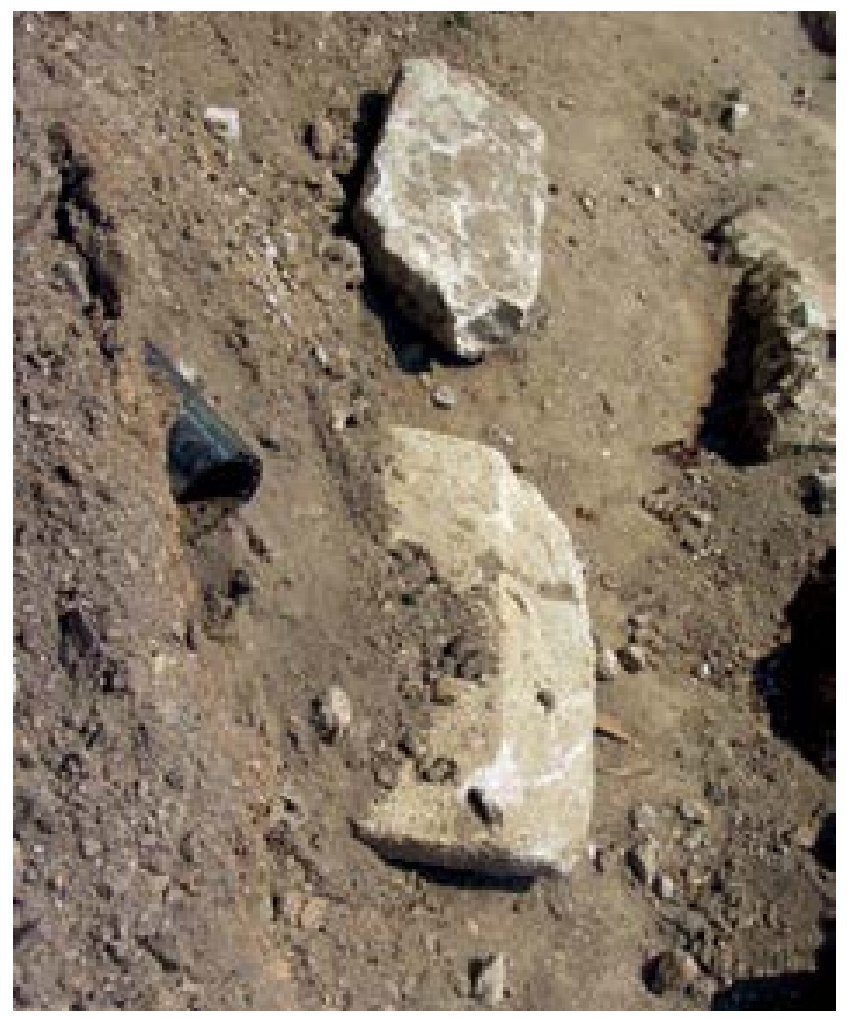

Sl. 15. Dijelovi srednjovjekovnih nadgrobnika

Fig. 15. Parts of the medieval tombstones

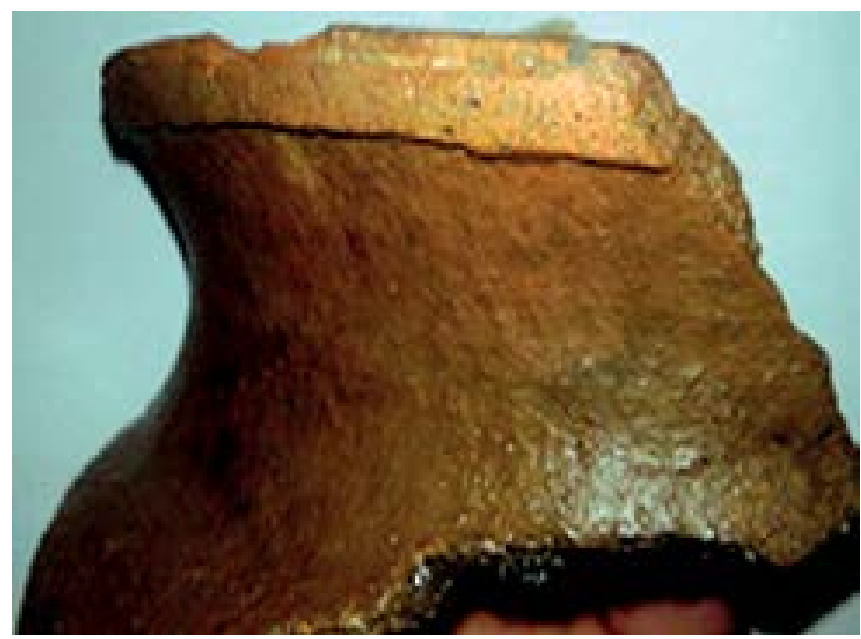

Sl. 16. Ulomak žute keramičke posude Fig. 16. Fragment of yellow ceramic bowl 
A. ŠKEGRO - A. SEJFULI - M. ĆORIĆ - CRKVINE U VESELOJ KOD BUGOJNA...

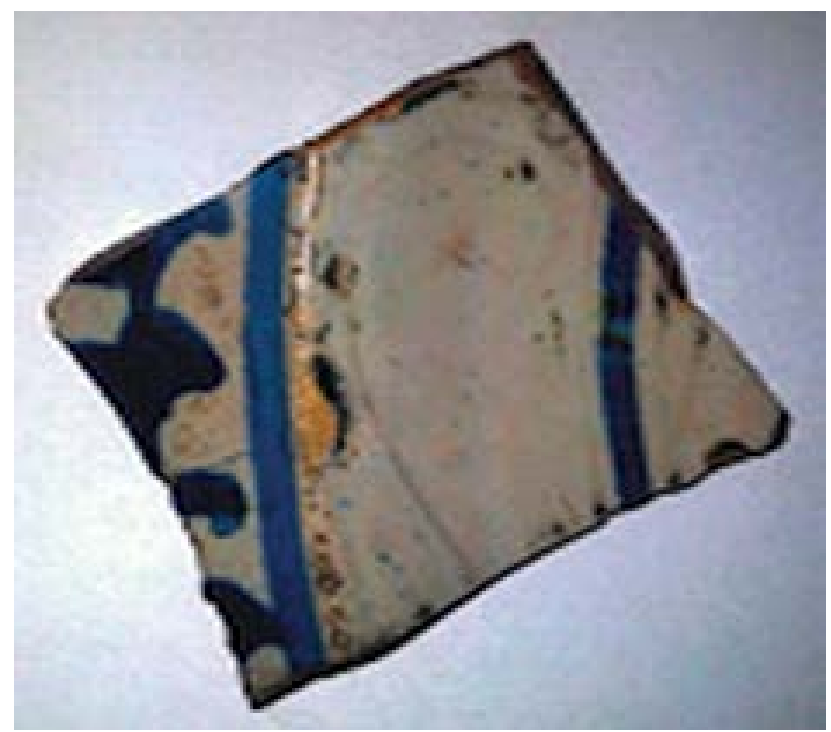

Sl. 17. Ulomak plave majolike

Fig. 17. Fragment of a blue majolica

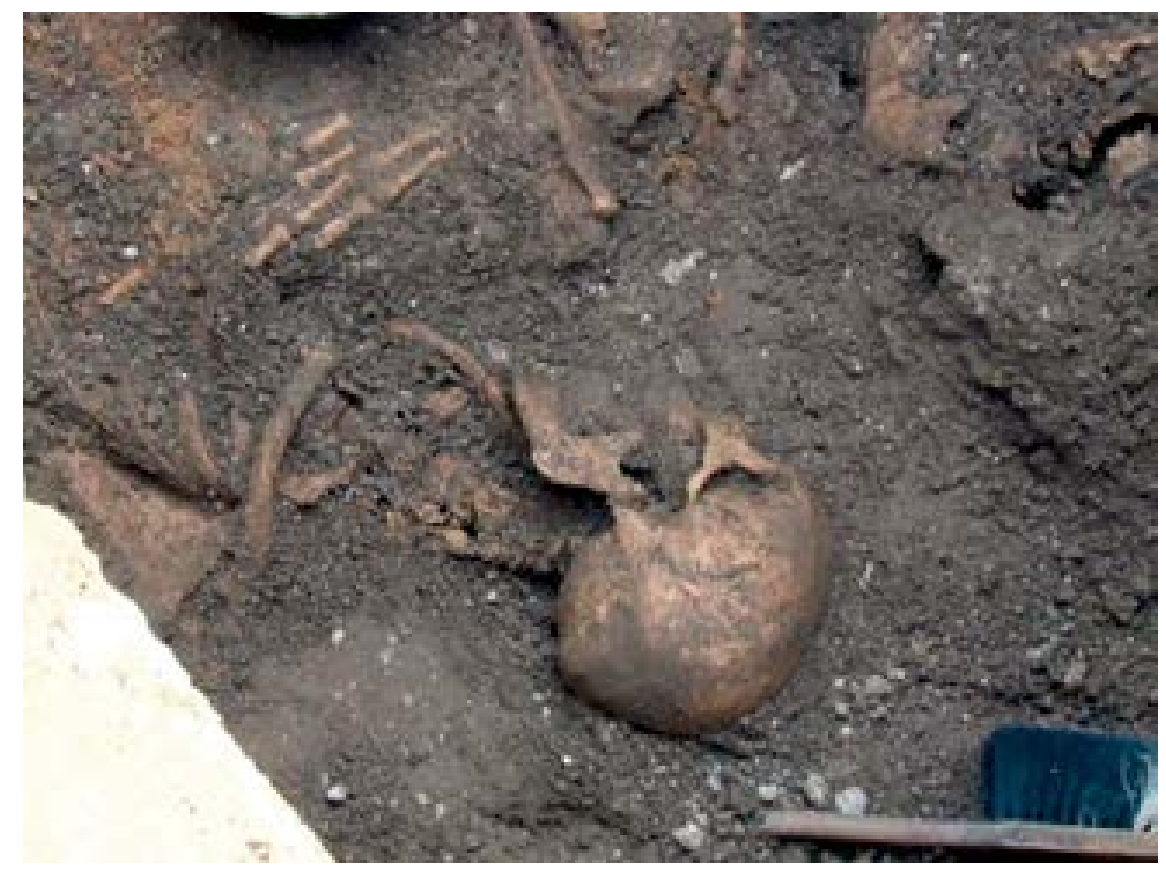

S1. 18. Skelet odrasle osobe iz sjeverozapadnoga dijela središnje prostorije Fig. 18. Skeleton of an adult from the northwerstern part of the central room 


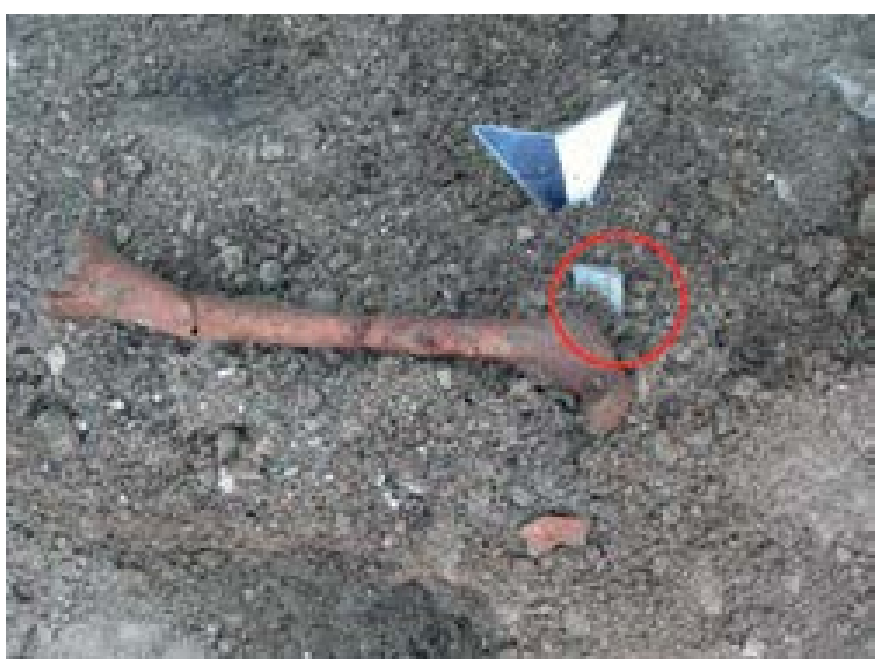

S1. 19. Bedrena kost sa svitkom olovnog lima iz sjeverozapadnoga dijela srednje prostorije

Fig. 19. Femur with a coil of sheet lead from the northwerstern part of the central room

\section{Treća faza iskopavanja}

Treću fazu iskopavanja objekta na Crkvinama, od 9. do 25. rujna 2015., izvodili su djelatnici Franjevačkog muzeja u Tomislavgradu 'Fra Jozo Križić.'. ${ }^{5}$ Tom prilikom "unutar zidina je pronađeno i 12 grobova sa skeletnim ostatcima. Posebno je zanimljiva grobnica u kojoj su pronađeni skeletni ostatci muškarca i žene prekriveni plaštom koji je prožet zlatnim i srebrnim nitima. Također, u grobnicama su pronađeni i zlatni predmeti te novčići i prstenje na rukama dviju osoba." ${ }^{59}$ Skeletni ostatci muškarca popraćeni su brokatnom

58 "Istraživanja su trajala od 9. do 25. 9. 2015. Voditelj istraživanja bio sam ja, angažiran od strane Franjevačkog muzeja u Tomislavgradu. Osim mene na istraživanju su sudjelovali mag. arheologije i povijesti umjetnosti Krunoslava Oreč i mag. arheologije i povijesti Nikša Grbić." Odgovor mag. Ljube Oreča od 12. 11. 2015. upućen Anti Śkegri.

59 "Jedan dan na Crkvinama s gospodinom Husejnom Smajićem", Tomislavcity. com. Početna stranica svih Duvnjaka, http://www.tomislavcity.com/index. php?option=com_content $\& v i e w=$ article $\&$ id $=7060$ :jedan-dan-na-crkvinama-s-gospodinom-husejnom-smaji\%C4\%87em\&catid=34\&Itemid=188 (27. 12. 2015). 
tkaninom, prstenom te s tri i pol venecijanska novčića iz 14. st. ${ }^{60} \mathrm{U}$ pitanju je grobnica "sa skeletnim ostacima i tkaninom sa zlatnim lamelama, nitima" u kojoj su pronađeni "skeleti žene i muškaraca, a tkanina protkana zlatnim nitima ukazuje da je riječ o ostatcima pripadnika visokog plemstva". ${ }^{61}$ Prema javnosti prezentiranim istraživanjima "na ostacima skeleta dvoje djece, rezultati su pokazali da se radi o djeci starosti od 3 do 4 godine odnosno od 4 do 6 godina. Jedno dijete je umrlo od anemije zbog nedostatka željeza u krvi, a uzrok tome je loša prehrana. Što se tiče dvojnog groba gdje su pokopani muškarac i žena, Kljajić je istaknula da je žena starija i životne je dobi u rasponu od 45 do 50 godina te da po analizi kostiju ima dosta osteoartritisa (bolest zglobova). Na čeljusti žene, prema njezinu izlaganju, ima veliki gubitak zuba, karijesa i svega ostalog dok muškarac dobi od 35 do 45 godina starosti ima odlične zube koji nisu istrošeni. Kod njega je, kaže, utvrđen lom ruke i upale po nogama odnosno potkoljenice. 'Kod njega postoji mogućnost da je lomom ruke zarazio tijelo čime su bakterije krvotokom došle na druge dijelove tijela poput navedene potkoljenice gdje je nakon nekog vremena nastupilo žarište vrlo ružnog izgleda, a uz to je veoma bolno', kazala je Kljajić. Uz to je još dodala da postoji mogućnost da je to i uzrok smrti kod ovog muškarca. Dok je antropologinja svjedočila o dosadašnjim rezultatima, na njezinu improviziranom stolu su se nalazile kosti petog pronađenog skeleta koje je po rasporedu složila čime je po nekim povredama zaključila da je ubijen. 'Palčana kost je odrezana, najvjerojatnije sabljom, također ima dosta dobre zube što daje mišljenje da su manje jeli ugljikohidrata odnosno žitarica dok su jeli više proteina tj, mesa', istaknula je dr. Marijana Kljajić."62

60 M. L. "Pronađeni skeleti u temeljima crkve iz 14. stoljeća u Bugojnu dopremljeni na analizu u Tomislavgrad", Dnevni list vaša dnevna novina, http://dnevni-list.ba/web1/pronadeni-skeleti-u-temeljima-crkve-iz-14-stoljeca-u-bugojnu-dopremljeni-na-analizu-u-tomislavgrad/ (27. 12. 2015).

61 A. Mandžić Bugojno: Otkopana grobnica pripadnika visokog plemstva?!, Bugojno danas, http://www.bugojno-danas.info/bugojno-otkopana-grobnicapripadnika-visokog-plemstva/ (11. 9. 2015); D. R. Nova arheološka otkrića na lokaciji Crkvina kod Bugojna. Nova arheološka otkrića pronađena su u rejonu Crkvina, na imanju Bugojanca Huseina Smajića iz Vesele, http://novovrijeme.ba/nova-arheoloska-otkrica-na-lokaciji-crkvina-kod-bugojna/ (11. 9. 2015).

62 M. L. "Pronađeni skeleti u temeljima crkve iz 14. stoljeća u Bugojnu dopremljeni na analizu u Tomislavgrad," Dnevni list vaša dnevna novina, http://dnevni-list.ba/web1/pronadeni-skeleti-u-temeljima-crkve-iz-14-stoljeca-u-bugojnu-dopremljeni-na-analizu-u-tomislavgrad/ (27. 12. 2015). 


\section{Pripadnost objekta}

Dimenzije, struktura zidova, izvedba dovratnika i nadvratnika te ukrašavanje freskama svjedoče da su objekt na Crkvinama tijekom kasnog srednjeg vijeka gradili i ukrašavali vrlo vješti graditelji za veoma moćnog investitora. U sumarnom popisu Bosanskog sandžaka iz 1468./1469. godine zabilježeno je da se Susid - jedna od tri predosmanlijske utvrde s područja Uskoplja - nalazi na području koje je bilo izravno kraljevsko vlasništvo (vilajet Kral). ${ }^{63}$ Budući da je čitavo Uskoplje bilo kraljevo vlasništvo (Scopia regiuncula), ${ }^{64}$ jasno je da je to bila i Vesela Straža. To potvrđuje i činjenica da je kralj Stipan Tomaš (1443.-1461.) iz Vesele Straže 13. listopada 1450. uputio pismo (Prilog br. 3) venecijanskom duždu Francescu Foscariju (1373.-1457.), kojim mu zahvaljuje što ga je uvrstio među svoje saveznike prilikom sklapanja mira s aragonskim kraljem Alfonsom V. (1416.-1458.) ${ }^{65} \mathrm{Da}$ je Vesela Straža bila kraljevsko vlasništvo proizlazi i iz toga što je 1456. godine u otimačini srebra jednog dubrovačkog karavana podno ovoga mjesta sudjelovao i kraljev dijak Stipan Milošević. ${ }^{66}$ Očito je ovaj objekt bio boravište bosansko-humskog kralja Stipana Tomaša, u gornjovrbaškom kraju (Uskoplju). U njegovoj je gradnji vjerojatno sudjelovao i Juraj Gradomilović, i sam rodom iz Vesele Straže, za kojeg se predmnijeva da je sudjelovao i u gradnji kraljevskoga Jajca. ${ }^{67} \mathrm{Na}$ povezanost graditelja Jajca i objekta na Crkvinama u Veseloj upućuje i profilirani ornament (tzv. dijamantna vrpca) s dovratnikâ zvonika sv. Luke u Jajcu (sl. 20). Nije isključeno da je objekt na Crkvinama

63 Sumarni popis Sandžaka Bosna iz 1468/69. godine. Dešifrirao i s osmanskoturskog jezika preveo, naučno obradio i za štampu priredio Ahmed S. Aličić, "Islamski kulturni centar Mostar", Mostar, 2008., str. 186.

64 Domenici Mari Nigri Veneti, Geographiae commentariorum libri XI, nunc primú in lvcem magno stvdio editi... Vna cvm Lavrentii Corvini nouoforensis Geographia, et Strabonis Epitome per D. Hieronymum Gemvsaevm translata ... Adiecto ... indice, "per Henrichvm Petri", Basileae, 1557., str. 91.

65 Константин Јиречек, Трговачки путеви и рудници Србије и Босне у средњем вијеку, Зборник Константина Јиречека, I, "Posebna izdaњa Srpske akademije nauka", kњ. CCCXXVI, Београд, 1959., str. 297, bilj. 284.

66 Михаило Динић, Земље Херцега Светога Саве, "Глас САНУ", бр. 182, Београд, 1940., str. 225; К. Јиречек, "Трговачки путеви", str. 297, bilj. 285: ma siando essi mercadanti zonti sotto Vesela Straxa, conte Pauao Modrinich et Stiepan Miloseuich, diach della Maiesta Vestra, tolseno e leuorno li ditti argenti.

67 Đ. BAsler, "Gradomilić Juraj", str. 445; Đoko MazAlić, Leksikon umjetnika slikara, vajara, graditelja, zlatara, kaligrafa i drugih koji su radili u Bosni $i$ Hercegovini, "Veselin Masleša", Sarajevo, 1967., str. 51. 

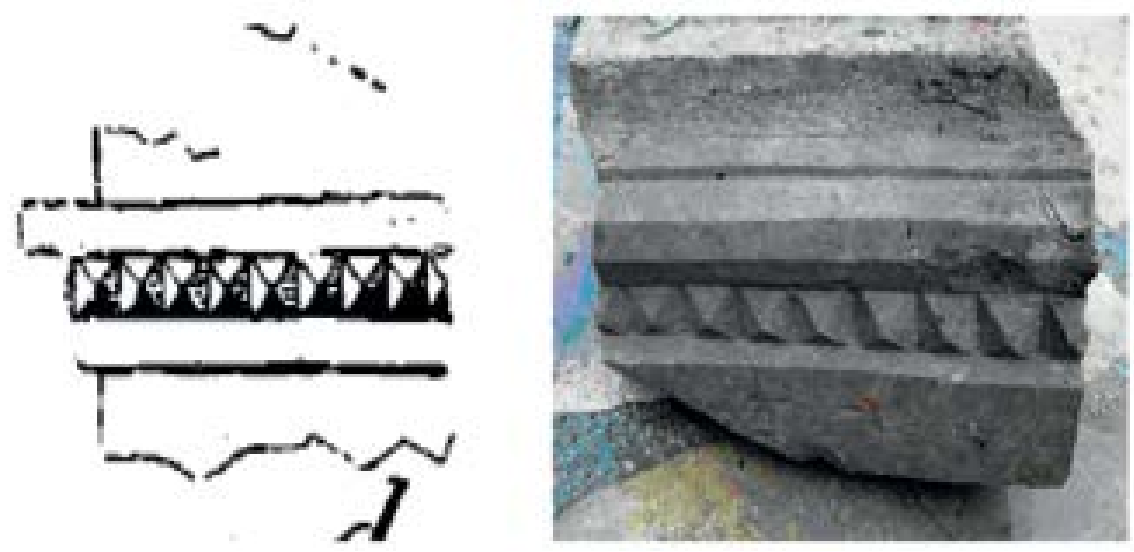

S1. 20. Ornament sa zvonika sv. Luke u Jajcu (lijevo) is Crkvina u Veseloj (desno) Fig. 20. Ornament from the bell tower of the St. Luke church in Jajce (left) and from the Crkvine location in Vesela (right)

freskama ukrašavao Dragić Medošević, rodom iz Bosanskog Grahova, koji je od 1453. do 1457. godine slikarstvo učio u radionici splitskog slikara Dujma. ${ }^{68}$ Bez sumnje je devastiran tijekom osmanlijskog osvajanja Uskoplja u proljeće 1463., odnosno njihova protjerivanja iz Bosne u ljeto i jesen iste godine. $U$ tim su se okolnostima mogli zbiti i ukopi unutar i oko ovoga objekta. Nakon izgona Osmanlija iz Bosne u ljeto i jesen 1463. godine kraljevski su posjedi dospjeli u ruke ugarsko-hrvatskog kralja Matijaša Korvina (1458.-1490.). Zbog zasluga u protjerivanju Osmanlija Matijaš Korvin je 6. prosinca 1463. Vladislavu Vukčiću Kosači (oko 1427.-1490.), sinu mu Balši i njihovim nasljednicima, dodijelio i posjede bosanskog kralja Veselu Stražu sa župom Uskoplje. ${ }^{69}$ Kako nisu imali drugog boravišta u ovoj župi, očito je i preuređivan za Kosače koji su iz njega upravljali ovom župom i ubirali prihode od karavanske trgovine. U prilog tomu govori i motiv crveno-bijelih pravokutnika s pokojim plavo-zelenim kvadratom $s$ freski iz njegove sjeverne prostorije. Isti se motivi nalaze i na štitu velikog vojvode hercega Stipana Vukčića Kosače (oko

68 M. Šunjić, "Postupni uspon", str. 12; Isti, Bosna i Venecija, str. 306.

69 Ludwig von Thallóczy, Studien zur Geschichte Bosniens und Serbiens im Mittelalter, "Verlag von Duncker \& Humbolt", München und Leipzig, 1914., str. 196-197, Nr. LXXX, str. 421: Preterea castra Vesela Straza et castrum - in comitatu de Usthopye et cum toto Usthopye. 


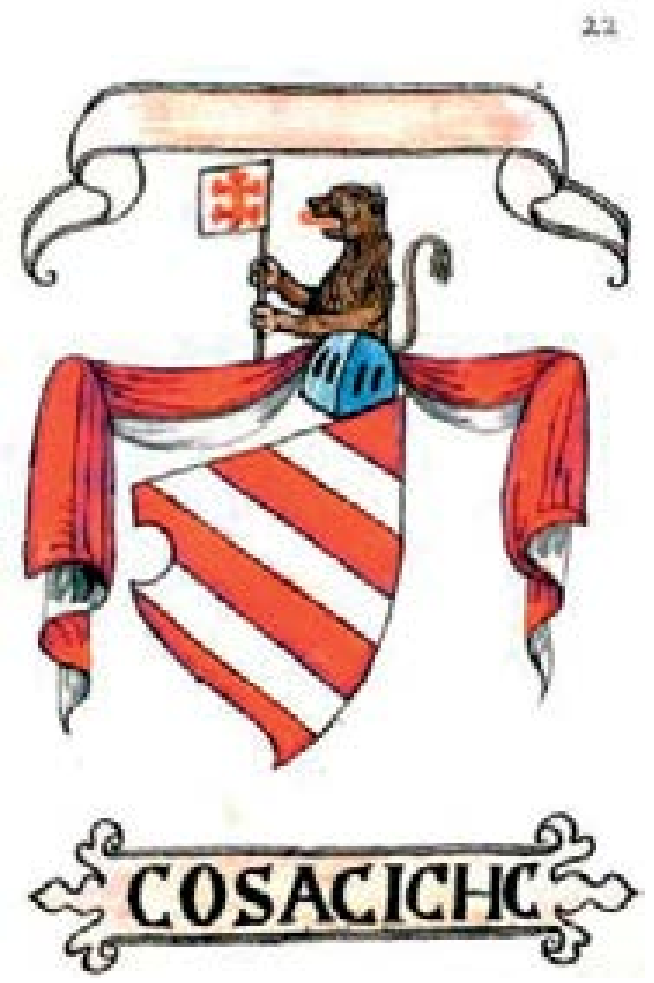

Prilog 2. Grb Kosačâ (prema Fojničkom grbovniku) Appendix 2. The Kosača's Family Coat of Arms (according to the Fojnica Armorial).

1404.-1466.) odnosno članova njegove obitelji (Prilog br. 2). ${ }^{70} \mathrm{O}$ građevinskim aktivnostima Vladislava Vukčića Kosače svjedoči i činjenica da je u ožujku 1464. godine tražio zidare čak i od Dubrovčana. ${ }^{71}$ Djelomično oslikavanje i tragovi krova samo u sjevernoj prostoriji svjedoče da objekt na Crkvinama nije bio dovršen odnosno obnovljen. Tome su bez sumnje pridonijela nemirna vremena tijekom kojih su Osmanlije ponovo ovladali Uskopljem u ljeto $1465 .{ }^{72}$ nakon čega

70 Fojnički Grbovnik. The Fojnica Armorial Roll, "Rabic", Sarajevo, 2005., str. 98-99; Fojnica Coats of Arms, "Franciscan Monastery Fojnica", Fojnica, 2012., str. 22.

71 Сима М. Ћирковић, Херцег Стефан Вукчић Косача и његово доба, Посебна издања САНУ, 376, Одељенје друштвених наука бр. 48, Београд, 1964., str. 259.

72 С. М. Ћирковић, Херцег Стефан, str. 257, 263. 
Vesela Straža zapada u drugi plan. Umjesto u to mjesto osmanlijski upravitelj okupiranih bosanskih prostora sandžak-beg Skenderbeg Mihajlović (1477.-1479.) boravi u Biogradu (Pruscu), odakle se u siječnju 1478. godine javlja Dubrovčanima. ${ }^{73}$ Nakon osmanlijskog preotimanja Uskoplja, uslijedio je i radikalni vjerski preokret pučanstva. ${ }^{74}$ Anadolski šejh Uvejz-dede proveo je islamizaciju katolika, koji "pod vodstvom svoga dušobrižnika, imenom Pandže, primi jednoga dana islam. Nakon toga je rečeni Pandža dolazio svaki dan Ajvaz Dedi na pouku u vjeri te je za godinu dana postao hafiz. ${ }^{75}$ Stoga mu je Ajvaz Dedo hajir-dovu (blagoslov) ostavio da u njegovoj porodici vazda hodža bude". ${ }^{76}$

\section{Zaključak}

Višekratna razaranja, devastiranja, prekapanja, destrukcija pa i iskopavanja provođena u neadekvatnim okolnostima, odnosno pomanjkanje kvalitetnog pokretnog arheološkog materijala, ne dopuštaju preciznije datiranje i definiranje objekta na Crkvinama u Veseloj kod Bugojna. Više je nego jasno da su ga gradili veoma vješti graditelji, koji su graditeljsko umijeće i slikarske vještine stjecali kod najistaknutijih dalmatinskih majstora. Nije isključeno da su u pitanju bili isti oni koji su gradili i objekte u 40 -ak km udaljenom kraljevskom Jajcu. Budući da je rodom bio iz Vesele Straže, nije neopravdano pretpostaviti da je u njegovoj gradnji, odnosno preuređivanju, bio angažiran i vrsni graditelj Juraj Gradomilović. Nedovršenost ovoga objekta upozorava da je preuređivan u burnim vremenima, očito za Vladislava Vukčića Kosaču - posljednjega predosmanlijskoga gospodara Uskoplja. Budući da je podignut na karavanskom putu, jasno je da se iz njega nadzirao i karavanski promet između Bosne i dalmatinskih komuna.

73 Ćiro Truhelka, "Tursko-slovjenski spomenici dubrovačke arhive", u: Glasnik Zemaljskog muzeja u Bosni i Hercegovini, br. XXIII., Sarajevo, 1911., str. 49-50, br. 56, Tab. VIII, str. 342-343.

74 Elvir Duranović, "Narodno predanje o Ajvaz-dedi, historijsko-komparativni pristup", u: Glasnik Instituta za islamsku tradiciju Bošnjaka Sarajevo, br. 9-10, Sarajevo, 2015., str. 968-969.

75 Háfizom / háfizom označava se ona osoba koja Kurıan zna naizust na arapskom i na materinjem jeziku.

76 ĆAzim Ruščuklija, "Ajvaz Dedo", u: Novi Behar, br. II/23, Sarajevo, 1929., str. 357; Muhamed Hadžıjahić, Porijeklo bosanskih Muslimana, "Bosna", Sarajevo, 1990., str. 110. 


\section{Povelja pripisana nepostojećem vikaru Bosanske franjevačke vikarije fra Marinu Splićaninu ${ }^{77}$}

\section{CCLII.}

Ostoya, Rex Bosnae, Fratribus Minoribus S. Francisci, bene meritis, Patronatum confert. A. 1406.

In nomine Dei Amen. Nos Frater Marinus a Spalato, Vicarius totius Bosnae, Ordinis Sancti Francisci, damus ad intelligendum hys nostris apertis literis, omnibus quibus conuenit, et specialiter Admodum Reuerendis, in Christo Fratribus dictae Vicariae Bosnensis, qui post nos erunt, et Custodibus, Guardianis et illorum Fratribus dictae Vicariae Bosnensis, praesentibus et post futuris: Quomodo Illustrissimus Dominus Rex Ostoya, de Bosna, considerando multa, diuersa, vera, grandia et fidelia seruitia, et solatia, quibuscum seruiuerunt et consolati sunt praedecessores Comitis Brayano Ohmuhchieuich, Gargurich, Antecessores dicti regis Ostoya et specialiter Vaiuoda Ghranisauo Omuchieuich, Gargurich, Pater nominati Comitis Brayano: et considerando seruitia postea facta dicto Regi Domino Ostoya, et eius filio Domino Stephano, ab nominato Comite Brayano et eius filiis Radiuojo, Stephano, et Radlav, transeunte heri aula per istum locum, Vesela Strascia, intrauit Ecclesiam,

\section{CCLII.}

Ostoja, kralj Bosne, povjerava zaštitu vrlo zaslužnoj Manjoj braći Sv. Franje, 1406. g.

U ime Božje. Amen. Ja, brat Marin Splićanin, vikar cijele Bosne, Reda Svetog Franje, ovom svojom okružnicom dajem na znanje svima kojih se to tiče, a posebice veoma poštovanoj braći u Kristu spomenute Bosanske Vikarije, onima koji će doći nakon nas, kustosima, gvardijanima i njihovoj braći spomenute Bosanske Vikarije, sadašnjima i onima poslije nas. Presvijetli gospodin kralj Bosne Ostoja, imajući na umu brojne, raznolike, istinske, veličanstvene i vjerne službe i utočišta, koje su preci kneza Brajana Ohmuhćevića Grgurića pružili i iskazali predšasnicima spomenutoga kralja Ostoje, a posebice vojvoda Granisav Omućević Grgurić, otac spomenutoga kneza Brajana; imajući na umu potom zasluge koje su imenovani knez Brajan i njegovi sinovi Radivoj, Stipan i Radlav iskazali spomenutome kralju gospodinu Ostoji i njegovome sinu gospodinu Stipanu, idući jučer iz dvora onim mjestom, Veselom Stražom, uđe u crkvu, održa govor i dođe nam na kapitul prethodno spomenuti gos-

77 Codex Diplomaticvs Hungariae Ecclesiasticvs ac Civilis, Tomi X. Volvmen IV. Ab anno 1401-1409., Stvdio et opera Georgii Fejér bibliothecarii regii, "Typis typogr. Regiae Vniversitatis Vngaricae", Budae, 1841., str. 552-555, br. CCLII. 
et facta oratione praedictus Dominus Rex Ostoya, et cum illo Comes Brayano Ochmuchieuich Gargurich, venit ad nos ad Capitulum, et ibi nobiscum quibusdam verbis collatis, manu prehendit Comitem Brayano, et sequentia loqui incepit: Reuerende Pater Vicari, et vos reliqui Patres Vicariae Bosnensis, quos Dominus Deus hic congregauit, Ecce nos Rex Ostoya damus Comitem Brayani Ochmuchieuich Gargurich, et eios filios Radiuoiuun (sic!), Stephanum, et Ravsaum, et illorum successores in brachia Ecclesiae (propter illorum fidelia seruitia, tempore, quo me expulit Bosna (quo in sola Ciuitate Bobvaz detinebar) cum illa libertate, et cum omni hoc, quidquid illorum antecessoribus in feudum antecessores nostri reges et Bani Bosnenses dederunt, quid et quid nos donauimus Ego et filius meus Stephanus, cum ciuitatibus, locis, vectigalibus, viris, praediis, et vasallis, cumque omni illorum possessione, quam habuerunt in Smuzka, et territorio Ciuitatis Tunchr, et aliud quidquid habuissent, cum omni hoc et quidquid residuum habent, sicut continent illorum priuilegia, obtenta a nostris Praedecessoribus Regibus et Banis Bosoniensibus, damus in manus Ecclesiae, et in receptionem vestram, et aliorum Patrum Vicariae Bosnensis, Vicariorum, Custodum, Guardianorum, et omnium Vestrorum fratrum dictae Vicariae, praesentium et futuror. et de isthoc in praesentiarum volo facere aperta nostra priuilegia sub nostris penden- podin kralj Ostoja i s njime knez Brajan Ohmučević Grgurić i tu nakon kratka razgovora s nekima od nas, za ruku primi kneza Brajana i poče ovako zboriti: "Poštovani oče vikaru i ostali oci Bosanske Vikarije koje je Gospodin Bog ovdje sabrao, evo ja, kralj Ostoja, predajem u ruke Crkve kneza Brajana Ohmućevića Grgurića i njegove sinove Radivoja, Stipana i Ravsava i njihove nasljednike (zbog njihove vjerne službe u vrijeme kad me Bosna izagna, kad sam boravio samo u gradu Bobovcu) s onom slobodom i svim ovim što su god naši predšasnici, kraljevi i banovi bosanski dali u posjed njihovim precima, a što smo i mi, ja i moj sin Stipan, darovali, s gradovima, mjestima, carinama, ljudima, posjedima i vazalima, i s čitavim njihovim posjedom kojega su imali u Smuzki ${ }^{78}$ i s područjem grada Tunhr ${ }^{79}$ i što su god drugo posjedovali i sa svim ovim i što god preostalo imaju, kao što su njihove povlastice koje su zadobili od naših predšasnika kraljeva i banova bosanskih, stavljamo u ruke Crkve, u vaše i okrilje drugih otaca Vikarije Bosanske, vikara, kustosa, gvardijana i sve vaše braće, sadašnje i buduće, spomenute Vikarije. I stoga sada želim svoje povlastice objelodaniti sa svojim visećim i uobičajenim pečatima, utisnutima i s jedne i druge strane. I zbog toga vam u ruke predajem kneza Brajana s njegovim gore spomenutim sinovima $\mathrm{i}$ njih stavljam u vašu zaštitu i njihove nasljednike onima koji će doći poslije

78 Smucka kod Tarčina - između Sarajeva i Konjica.

79 Tuhelj kod Tarčina - između Sarajeva i Konjica. 
tibus et solitis sigillis ex vna et altera zona sigillatis. Proptereaque vobis dono Comitem Brayano, cum eius supra scriptis filiis, in Brachia, et in protectionem vestram et illorum successores illis, qui post nos erunt. Et si accideret, quod aliquando nos (a quo Deus nos custodiat) aut meus filius Stephanus seu alter noster successor, per aliquam malam voluntatem, aut per aliquam malam informationem vellet aliquam molestiam facere Comiti Brayano, et supra dictis eius filiis, aut illorum successoribus, contra illorum haec priuilegia, aut facere vellet illis qualecunque aduersum negotium, quod prius conclusum non fuisset, cum iustitia Ecclesiastica, volumus, vt vos illos protegatis, et defendatis ratione illorum instantiae contra nos, seu contra filium meum, Stephanum et illius successores, cum omni iustitia, et canonibus ecclesiasticis, et contra omnes illos, qui post nos futuri sunt, per suos et suorum successores; et non concedatis illis vlla ratione, supra dicta priuilegia et scripturas rumpere, neque supra illas aliquas oppositiones fieri. Interea Nos Frater Marinus supradictus Vicarius Boznensis, cum omnibus Patribus, qui in praesentiarum ad ista conuenerunt, in supra dictum nostrum Capitulum, videndo et considerando, quod supra dictus Illustrissimus Dominus Rex Ostoja cum nostra interuentione non requisitus, non rogatus, solum ex sola sua bona voluntate et regia gratia vellet Comitem Brayano et eius suprascriptos filios, cum adeo fortibus scriptis, et grandi libertate, in manus et protectionem Ecclesiae dare et commendare, oramus et commendamus omnibus $\mathrm{Pa}$ - nas. A ako bi se dogodilo da bih jednom ja (od čega neka me Bog čuva) ili moj sin Stipan ili neki drugi moj nasljednik u kakvoj zloj volji ili nekoj lošoj namjeri htio nanijeti kakvu nepriliku knezu Brajanu i gore spomenutim njegovim sinovima ili njihovim nasljednicima protiv ovih njihovih povlastica ili bi im htio učiniti bilo kakav nepovoljan čin koji ne bi bio prethodno zaključen s crkvenom pravičnošću, želimo da ih vi štitite i branite zbog njihove sadašnje blizine prema meni ili prema mome sinu Stipanu i njegovim nasljednicima sa svom pravednošću i crkvenim zakonima, i protiv svih onih koji će poslije nas biti, pomoću svojih i njihovih nasljednika; te da im ni iz kojega razloga ne dopustite nastupati mimo rečenih povlastica $i$ pisama niti da mimo njih bude ikakvih protivština." Zato ja brat Marin, gore spomenuti bosanski vikar, sa svim ocima koji su se sada sabrali na naš gore rečeni kapitul, gledajući i promišljajući kako gore spomenuti presvijetli gospodin kralj Ostoja, niti pitan niti zamoljen našim posredovanjem, nego slobodnom svojom voljom i kraljevskom milošću želi kneza Brajana i njegove gore navedene sinove s tako čvrstim pismom i s odlučnom samostalnošću predati i povjeriti u ruke i zaštitu Crkve, molimo i povjeravamo svim ocima i poglavarima, sadašnjim i budućim u Bosanskoj Vikariji, ako bi u neko vrijeme (što neka Bog odvrati) gore rečeni presvijetli kralj Ostoja ili neki njegov nasljednik želio gore navedenom knezu Brajanu i njegovim sinovima ili njihovim nasljednicima učiniti neki nemio čin ili nastupati protiv njihovih povla- 
tribus et superioribus praesentibus et futuris in Vicaria Bosnensi, quod si in aliquo tempore (quod Deus auertat) supra dictus Illustrissimus Rex Ostoya, vel aliquis eius successor, vellet supra scripto Comiti Brayano, et eius filiis, aut illorum successoribus facere aliquod aduersum negotium, aut progredi contra illorum priuilegia, quae habent, ad illorum instantiam vellent protegere illos, et defendere cura omni iustitia Canonum Ecclesiasticorum, sicut filios Brachii Ecclesiae, ei non concedere, vt haec illorum priuilegia, libertates, scripturae, et firmitates, vllo modo illis deficiant. Scriptum Veselae decima quinta die Mensis Maii, a $\mathrm{Na}$ tiuitate Christi A. MCCCCVI."

L. S. pend.

Ex archiuo FF. Minorum, Prouinciae Saluatoris Sancti Francisci. stica koje imaju, neka ih s obzirom na njihovo sadašnje stanje nastoje štititi i pomno braniti sa svom pravičnošću crkvenih zakona kao sinove tijela Crkve, neka ne dopuste da im ove njihove povlastice, slobode, povelje i samostojnosti ni na koji način ne umanje.

Pisano u Veseloj, 15. svibnja 1406. godine od Kristova rođenja.

$\mathrm{M}$ (jesto) $\mathrm{P}$ (ečata) vis(ećeg)

Iz arhiva Manje braće Svetoga Franje, Provincije Spasitelja 
PRILOG BR. 3.

\section{Kralj Stipan Tomaš zahvaljuje venecijanskom duždu koji ga je uvrstio medu svoje saveznike u mirovnom sporazumu sklopljenom s aragonskim kraljem $^{80}$}

1450. 13. octobris. Litera serenissimi domini regis Bosne supra denominatione pacis. Illustrissimo ac potenti viro domino Francisco Foscari duci Venetiarum etc. salutem, sinceram dilectionem. Sthephanus Thomas dei gratia rex Bosne etc. Nuper cum magna animi nostri jocunditate recepimus literas vestre excellentie plenas amoris et erga nos immense caritatis. Non enim possumus non gaudere, quando intelligimus principes mundi, maxime quos una catholica fides claros facit, in unum convenire, et ab illis recedere, qui non solum detrimento sunt bonis his exterioribus, sed anime quoque plurimo periculo. Scimus enim et nimium experimento, quod dolenter referimus, notum est nobis, quod mala strepitus armorum et hostiles incursus pariunt, que eo detestabiliora sunt, quo inter fideles seviunt. Pacem igitur inter illustrissimum vestrum dominium et serenissimum regem Aragonum gratissimam habemus, eaque ut firma et stabilis sit, Deum oramus. Nominationem insuper et comprehensionem nostram a vestra excellentia factam, ratam habemus, vobis gratias agentes,
13. listopada 1450. Pismo presvijetloga gospodina kralja Bosne o imenovanju u svezi s mirom.

Preslavnomu i moćnomu mužu, gospodinu Francisku Foskaru, duždu Venecije ${ }^{81}$ itd. pozdrav i iskreno štovanje!

Stipan Tomaš, milošću Božjom kralj Bosne itd. S velikim ushitom svoje duše primili smo nedavno pismo Vaše Visosti, puno ljubavi i neizmjernog milosrđa prema nama. Ne možemo se, dakle, ne radovati kada vidimo kako se svjetski prvaci, koje samo katolička vjera čini slavnima, ujedinjuju i udaljuju od onih, koji štete ne samo ovim materijalnim dobrima, nego su i strašna opasnost po dušu.

Znamo, naime, i iz iskustva nam je itekako jasno, što sa žalošću iznosimo, da zveket oružja i neprijateljski napadi rađaju zlima, koja su tim odvratnija kad bjesne među vjernicima.

Stoga mir između vašega preslavnoga gospodstva i presvijetloga kralja aragonskoga smatramo osobito korisnim i molimo Boga da bude čvrst i trajan.

80 Šime LJubić, Listine o odnošajih između Južnoga Slavenstva i Mletačke republike, knjiga IX. od godine 1423. do 1452, Jugoslavenska akademija znanosti i umjetnosti, Zagreb, 1890., str. 356.

81 Venecijanski dužd Francisco Foscari (1423.-1457.). 
quod nostri honoris tantum memor est vestra celsitudo; sed de hoc tantum impresentiarum, ut constet de nostra acceptatione et sincera voluntate in his, que fecistis pro nostro honore. Cum celeritate namque possibili mittemus super hoc pro nostri honestate et negotii exigentia nostros oratores ad vestram excellentiam, qui etiam nostras super hanc nostre nominationis ratificationem patentes literas deferent, et qui de nostra affectatione singulari ad illud illustrissimum vestrum dominium informabunt. Quod autem tardius, quam vellemus, de hoc avisamus vestram celsitudinem, fecit tarda receptio literarum vestrarum, que solum nudius tercius ad nos delate sunt, cuius culpa nescimus. In Christo valeat vestra celsitudo. Ex Veselastrazza XIII octobris MCCCCL.
Povrh toga, prihvaćamo imenovanje i naše uvrštavanje [među saveznike] koje je Vaša Visost učinila, zahvaljujući Vam što se Vaša Uzvišenost toliko sjeća naše časti. Ali za sada o ovome tek toliko, da bi bilo jasno naše prihvaćanje i iskrena namjera u ovome što ste za našu čast učinili.

Naime, u svezi s ovim Vašoj ćemo Visosti, koliko je moguće žurno, radi naše časti i zaključenja sporazuma uputiti svoje izaslanike, koji će, dakako, u svezi s ovim donijeti punomoći o prihvaćanju našega imenovanja i koji će o našoj posebnoj odluci izvijestiti preslavno Vaše dostojanstvo.

A što Vašu Uzvišenost o ovomu izvješćujemo kasnije nego li želimo, to je zbog zakašnjelog prispijeća Vašega pisma, koje nam je tek prekjučer doneseno. Zbog čijeg propusta, nije nam znano.

Zdrava bila Vaša Uzvišenost u Kristu!

Iz Vesele Straže, 13. listopada 1450. 


\section{Late Medieval Locality "Crkvine" in the Village of Vesela near Bugojno in the Western Part of Central Bosnia}

\section{Summary}

There has been general consensus amongst scholars that Franciscans owned a church and a monastery in Vesela Straza near Bugojno (western part of central Bosnia), which were demolished during the Ottoman assaults on the core of the Bosnian kingdom in the first half of the $15^{\text {th }}$ century. The objects were mentioned in one falsified charter dating from $15^{\text {th }} / 16^{\text {th }}$ century, as well as by three Franciscan chroniclers in the $17^{\text {th }} / 18^{\text {th }}$ century and by a Franciscan travel writer from the $19^{\text {th }}$ century. These structures have been attributed to the Crkvine location, in the vicinity of the medieval fortress Vesela Straza. Excavations performed on the site from $10^{\text {th }}$ to $20^{\text {th }}$ December 2014, from $8^{\text {th }}$ to $14^{\text {th }}$ June 2015 and from $9^{\text {th }}$ to $25^{\text {th }}$ September 2015 have not brought to light any evidence which could undoubtedly prove these claims. The absence of tiles and bricks, as well as traces of burnings, witness that the object on the Crkvina location has been covered with shakes (type of wooden shingle) and that it has been destroyed by fire. Its dimensions, wall structure, door-posts, lintels and frescos speak in favour of the claims that it was a structure which belonged to the highest ranks of the Bosnian-Hum political elite. It is not excluded that the location has been named "Crkvine" because Catholic religious services have been performed at the remains of the former church.

Keywords: Crkvine; Vesela Straza; Bugojno; late Middle Ages. 